\title{
Abiotic Stress in Plants; Stress Perception to Molecular Response and Role of Biotechnological Tools in Stress Resistance
}

\author{
Qari Muhammad Imran ${ }^{1,2,+}$, Noreen Falak ${ }^{2,+}$, Adil Hussain ${ }^{3} \mathbb{D}$, Bong-Gyu Mun ${ }^{2}$ and Byung-Wook Yun ${ }^{2, * \mathbb{D}}$ \\ 1 Department of Medical Biochemistry, Biophysics, Umea University, 90187 Umea, Sweden; \\ muhammad.imran@umu.se.com \\ 2 School of Applied Biosciences, Kyungpook National University, Daegu 41566, Korea; \\ noorfalak.pk@gmail.com (N.F.); mun0301@naver.com (B.-G.M.) \\ 3 Department of Agriculture, Abdul Wali Khan University, Mardan 23200, Pakistan; \\ adilhussain@awkum.edu.pk \\ * Correspondence: bwyun@knu.ac.kr; Tel.: +82-5395-05712 \\ + These authors contributed equally.
}

Citation: Imran, Q.M.; Falak, N : Hussain, A.; Mun, B.-G.; Yun, B.-W. Abiotic Stress in Plants; Stress Perception to Molecular Response and Role of Biotechnological Tools in Stress Resistance. Agronomy 2021, 11, 1579. https://doi.org/10.3390/ agronomy11081579

Academic Editor: Jane K. Dever

Received: 16 June 2021

Accepted: 2 August 2021

Published: 9 August 2021

Publisher's Note: MDPI stays neutral with regard to jurisdictional claims in published maps and institutional affiliations.

Copyright: (c) 2021 by the authors. Licensee MDPI, Basel, Switzerland. This article is an open access article distributed under the terms and conditions of the Creative Commons Attribution (CC BY) license (https:// creativecommons.org/licenses/by/ $4.0 /)$.

\begin{abstract}
Plants, due to their sessile nature, face several environmental adversities. Abiotic stresses such as heat, cold, drought, heavy metals, and salinity are serious threats to plant production and yield. To cope with these stresses, plants have developed sophisticated mechanisms to avoid or resist stress conditions. A proper response to abiotic stress depends primarily on how plants perceive the stress signal, which in turn leads to initiation of signaling cascades and induction of resistance genes. New biotechnological tools such as RNA-seq and CRISPR-cas9 are quite useful in identifying target genes on a global scale, manipulating these genes to achieve tolerance, and helping breeders to develop stress-tolerant cultivars. In this review, we will briefly discuss the adverse effects of key abiotic stresses such as cold, heat, drought, and salinity. We will also discuss how plants sense various stresses and the importance of biotechnological tools in the development of stress-tolerant cultivars.
\end{abstract}

Keywords: heat stress; cold stress; drought stress; salinity; stress sensors; CRISPR-cas9

\section{Abiotic Stress; Problems and Damages}

Abiotic stress corresponds to any environmental factor that can limit plant growth and productivity. Historically, abiotic stress became the focus of plant scientists and agronomists in the past half-century due to rapid growth in human populations (which threatened global food security). Increasing food demand made it inevitable to investigate the reasons for reduced crop production that would often be ignored. It was around this time when scientists started making estimations concerning the loss of crops caused by environmental constraints and investigating the reasons behind it. In the early 80s, Boyer [1] estimated that environmental factors may reduce crop production by as much as $70 \%$. Since then, several reports have been published mentioning crop loss due to various abiotic stresses $[2,3]$. Some of these stresses cause irreversible effects to cultivated lands and ultimately affect crop production and quality. Although it is difficult to estimate the effects of abiotic stresses on agricultural lands, Cramer, et al. [4] have mentioned a rough calculation based on FAO reports mentioning that about $96.5 \%$ of global rural land is affected by abiotic stresses. He also mentioned a breakdown of this percentage contributed by each stress [4]. In a persistently changing environment, there are several adverse factors such as heat, cold, drought, and salinity (among others) that can affect both agricultural land and crop production. Here, we will take into account some of these major factors and their impact on plant yield and production. We shall also investigate the response and sensing mechanism 
of plants towards these adversities. Lastly, we will describe the role of new molecular tools such as RNA-seq and CRISPR in resistance towards stresses.

\subsection{Heat Stress}

Global warming is becoming one of the most serious concerns for plant scientists since the gaseous emissions and other related human activities are substantially adding to greenhouse gasses accumulation. Various global circulation models have predicted that greenhouse gasses (particularly $\mathrm{CO}_{2}$, methane, nitrous oxide, and chlorofluorocarbons) will gradually increase the global ambient temperature. The Inter-Governmental Panel on Climatic Change (IPCC) in their report has mentioned that the global average temperature will rise at a rate of $0.3{ }^{\circ} \mathrm{C}$ per decade [5]. At this rate, we will expect about a $1{ }^{\circ} \mathrm{C}$ increase in global temperature by 2025 [6] which could be quite serious when we are expected to have to feed about nine billion people by the year 2050 [7].

Temperature is one of the important factors in the maintenance of cellular metabolism and its rise above optimum levels is perceived as heat stress by plants. Wahid et al. [6] defined heat stress as an increase in temperature beyond a certain level for a period sufficient to cause irreparable damage to plant health. Generally speaking, a transient rise in temperature $\left(10-15^{\circ} \mathrm{C}\right)$ is termed as "heat shock." However, heat stress is a combination of complex processes including intensity duration and the rate of increase in temperature above optimum levels. The magnitude of heat stress in a particular climatic zone depends on the frequency and period of heat stress during the day and night. Heat can, therefore, disturb cellular homeostasis, ultimately leading to growth retardation and even death [8] and is a major threat to crop production worldwide [9]. Rises in temperate may lead to geographical redistribution and changes in growing seasons for major agriculturally important crops such as rice, wheat, and corn due to changes in the optimum temperature for crop maturity, etc., thereby affecting agriculture and livestock directly and humans indirectly. For example, Porter [10] reported that rising temperatures could extend the growing season of pasture grasses by allowing the optimum temperatures for starting growth to be reached sooner. Reports suggested that higher temperatures shorten the life cycle of most cereals, inducing senescence and reducing the duration of the growing season. Staple crops (e.g., corn, wheat, and rice) can only tolerate a narrow range of temperature which, if exceeded during floral transition, can damage seed production, and thus reduce crops yield.

Table 1 shows various studies mentioning heat, cold, drought, and salinity stress in several species. However, these are few examples, and the number of studies is growing owing to the importance of the matter. The PubMed database shows about 6404 articles that were published related to abiotic stress in plants in 2020 alone, despite the global crises of COVID19. This shows the urgency of the problem and the interest of plant scientists in the field.

\subsection{Cold Stress}

Cold is another environmental factor that limits the growing seasons of many plant species (Guy, 1990). The implications that cold stress have upon crops are important to understand., since a majority of the agriculturally important crops that are consumed by humans such as maize, rice, tomato, and fruits such as banana, mango, and papaya are from tropical or subtropical regions and are sensitive to chilling [11,12]. Cold stress is often differentiated into freezing and chilling stresses. The effect of cold stress on plants depends on the severity of the stress and the exposure time. The seedling stage of the plant is mostly affected by the cold. Common symptoms include the appearance of the surface lesion, discoloration, desiccation, induced senescence, reduced shelf life, ethylene production [11], etc. In addition to profound phenotypic changes, chilling brings drastic biochemical and physiological changes that have been reviewed in detail $[4,13]$. Briefly, these changes include an increase in cellular $\mathrm{Ca}^{+}$contents, an accumulation of reactive oxygen species (ROS) [4], a decrease in membrane fluidity due to unsaturation of fatty acid 
in the membrane, and compositional changes in lipids to protein ratio in the membrane [14]. In addition, low temperatures can also cause dehydration, mainly due to an inability to uptake water. Similarly, freezing can cause membrane damage due to drastic dehydration accompanied by ice formation. The formation of ice in intracellular spaces can cause a physical disruption of cells and tissues. Freezing can also cause protein denaturation and solute precipitation [15]. Like other abiotic stresses, both freezing and chilling induce the production of ROS, thereby disturbing cellular redox status.

\subsection{Drought Stress}

Drought is one of the major environmental stresses which causes a severe reduction in crop yield [16]. Climate changes impacting variability in rainfall in addition to growing water demand and diminishing water supply may increase water deficit conditions [17]. This will affect all organisms but will particularly affect plants that do not have mobile structures allowing them to migrate elsewhere when food and water are limited, thereby impacting crop production. The severity of the damage caused by drought stress is challenging, since it is driven by several factors such as rainfall patterns, the water holding capacity of the soil, and water losses due to evapotranspiration [16]. The impact of drought stress on crop species associated with growth and physiology has been well-explored [18,19]. A study mentioning analyses of data published between 1980 and 2015 on a global scale suggested $21 \%$ and $40 \%$ yield reductions in wheat and maize, respectively, due to drought [18]. Major effects of drought include poor germination [20,21], reduced seedling growth [22], reduce nutrient availability, photosynthesis, [23], number of leaves and size of individual leaf size [24], plants' fresh and dry weight [25], etc. In addition, exposure to drought may result in complete sterility in pearl millet (Pennisetum glaucum L.), probably due to disturbed assimilate movement to the developing ear [26]. Similarly, dehydration can reduce the production of coffee by as much as $80 \%$ [27]. A study by Franchini, et al. [28] reported that in the state of Parana, Brazil, in $2008 / 2009$, soybean harvest was reduced by $80 \%$ during a 45 -day drought in certain areas. Plants respond to drought through several factors including physiological changes such as stomatal closure [16], reducing transpiration [29], etc. In addition, plants induce changes in gene expression to expedite tolerance against drought stress.

\subsection{Salinity Stress}

Salinity in water or soil is another abiotic factor that can limit crop production specifically in arid or semi-arid regions [30]. According to an estimate published in 2011, over 800 million hectares of world land are affected by high levels of salinity [31]. Similarly, the same study reported that about 17 million hectares of agricultural land will be affected by salinity by 2050 . The adverse effects of salinity on plants are associated with the low osmotic potential of soil, nutritional imbalance, specific ion effect, or a combination of all these factors $[32,33]$. These factors have severe effects on plant growth and development at various levels [34]. General effects include reducing the growth rate, smaller and fewer leaves, and reduction in root length [35]. The osmotic effect of salinity contributes to changes in leaf color and developmental aspects such as root/shoot ratio and maturity rate [36]. As with other abiotic stresses, the effects of salinity on plants and their response towards it depends on the duration and severity of the stress. Generally, salinity has short term effects (such as ion-independent growth reduction) that take place within minutes to hours or days after perception of the stimuli, close stomata and inhibition of cell expansion which is shoot specific [35,37], and long-term effects which can occur over days or even weeks (such as building up cytotoxic ion levels, slowing down the metabolic activities and causing early senescence and ultimately cell death) [38,39]. A plant's tolerance to salinity is achieved by a multitude of physio-molecular mechanisms, osmotic and ionic tolerance, and tissue tolerance $[39,40]$. Among these, osmotic tolerance is a rapid response associated with a quick decrease in stomatal conductance to store water which employs fast signaling mechanisms between roots and shoots [39,41,42]. The ionic tolerance is achieved by activation of several signaling cascades that restrict net $\mathrm{Na}^{+}$influx and reduce 
net $\mathrm{Na}^{+}$translocation [43]. The tissue-specific tolerance is achieved by translocation of toxic ions to the vacuole to avoid their detrimental effects on cytoplasmic-based metabolic processes [43]. The salt overly sensitive (SOS) pathway comprising of different SOS genes, in this case, is the key to direct toxic ions to the vacuole [44].

\subsection{Heavy Metal Stress}

Heavy metals (HMs) such as $\mathrm{Mn}, \mathrm{Cu}, \mathrm{Ni}, \mathrm{Co}, \mathrm{Cd}, \mathrm{Fe}, \mathrm{Zn}$, and $\mathrm{Hg}$, etc. have been accumulated in soils due to several anthropogenic activities such as fertilizer application, improper disposal of industrial wastes, irregulated sewage disposals $[45,46]$, or pococurante disposal of automobile effluents. From soil, they are leached to groundwater or accumulated on the soil surface $[46,47]$. One of the severe aspects of HM stress is that it is non-biodegradable (that is, it cannot be vanished from the environment by natural means). HM stress has adverse effects on enzymes by inactivating or denaturing them. Reports suggested that HMs interfere with the substitution reaction of essential metallic ions with biomolecules that disturb the integrity of membranes, causing changes in photosynthetic ability, respiration, etc. [48]. HMs also induce oxidative stress by stimulating the production of hydrogen peroxide $\left(\mathrm{H}_{2} \mathrm{O}_{2}\right)$, superoxide radicals $\left(\mathrm{O}^{-}{ }_{2}\right)$, and hydroxyl radicals $(\mathrm{OH})[45,49]$. Accumulation of $\mathrm{HMs}$, particularly in roots due to their blockage by Casparian strips or trapping by root cell walls, impairs physio-morphological functions in plants which ultimately limits crop productivity [50].

Plants deploy both physiological and molecular mechanisms to cope with HMs. First, plants reduce the uptake of metals with the help of cellular and root exudates which halt the metals from entering the cell by increasing the efflux (a mechanism of stress avoidance) [45]. Many plants have specified mechanisms to cope with a particular type of $\mathrm{HM}$ by sequestering it in cellular compartments to protect the sensitive cellular components from interacting with these metals [45]. This mechanism involves compounds such as glutathione, phytochelatins, metallothioneins, amino acids, and certain enzymes such as superoxide dismutase (SOD) [48]. Interestingly, plants also use their symbiotic relationship with mycorrhizal fungi by making them decoy to accumulate HMs in the rhizosphere thus preventing their availability for plants [45]. There are several other ways that a plant can deal with HMs including changing the $\mathrm{pH}$ of the rhizosphere (resulting in precipitation of HMs), transporting the metallic ions from symplastic to aplastic space using metal transport and carrier proteins, secretion of root exudates such as malate and oxalate [51,52], the release of nitric oxide (NO) (which induces the antioxidant system and helps in HM stress alleviation $[53,54])$, use of phytochelatins to transport metallic ions via xylem and phloem [48], etc. However, we will focus more on molecular responses by plants towards HM stress. Transcriptomic studies have shown more than 30 candidate genes that were highly expressed in metal hyper-accumulator Arabidopsis helleri compared to the non-accumulator $A$. thaliana showed higher expression [55]. Reports suggested that the $\mathrm{Zn}^{2+}$ transporter AnT1 is overexpressed in the Noccaea caerulescens, which is a hyperaccumulator compared to the non-accumulator $N$. arvense [56]. Major candidate genes are those coding metal pumps belonging to the heavy-metal ATPase (HMA) family transporters. As the name indicates, they are responsible for the translocation of metals across biological membranes. For example, HMA2 and HMA4 induce metal efflux out of the cell in A. thaliana [57]. Similarly, MTP1, a member of the cation diffusion facilitator (CDF) protein family (which acts as a vacuolar membrane transporter), was highly expressed in hyperaccumulating plants of $A$. helleri compared to the non-accumulator [58]. As with other stresses, plants activate signaling cascades in response to HM stress. The most common of these are the mitogen-activated protein kinase (MAPK) cascade, reactive oxygen species (ROS) signaling pathway, and Ca-Calmodulin pathway [45]. 
Table 1. A list of various studies concerning cold, heat, salt, and drought stress in plants.

\begin{tabular}{|c|c|c|c|}
\hline Abiotic Stress Condition & Plant/Crop Species & Key Parameters Studied & Reference \\
\hline \multirow{10}{*}{ Cold stress } & Arabidopsis & Gene expression & [59] \\
\hline & Arabidopsis & Hormone signaling & [12] \\
\hline & Blue berry & Dehydrinn accumulaiton & [60] \\
\hline & Hibiscus & Photosynthesis & [61] \\
\hline & Candyleaf & Photosynthesis carbohydrates & [62] \\
\hline & Wheat & Antioxidant system/electron transport & [63] \\
\hline & Grapevine & WRKY TF expression & [64] \\
\hline & Arabidopsis & Nuclear proteome & [65] \\
\hline & Rapeseed & Microarray analyses & [66] \\
\hline & Rice & DNA methylation & [67] \\
\hline \multirow{9}{*}{ Heat stress } & Strawberry & Peroxidase activity, total protein content & [68] \\
\hline & Tomato & Chlorophyll fluorescence & [69] \\
\hline & Soybean & Proline content, NADP levels & [70] \\
\hline & Tobacco & Proline, polyamines & [71] \\
\hline & Tomato & Heat shock transcription factors and genes & [72] \\
\hline & Arabidopsis & Carbohydrate accumulation & [73] \\
\hline & Arabidopsis & Transcriptome profiling, autophagy & [74] \\
\hline & Arabidopsis & Circular RNAs & [75] \\
\hline & Rice & biomolecular fluorescence complementation (BiFC) & [76] \\
\hline \multirow{8}{*}{ Salt stress } & Maize & Antioxidant enzymes, lipid peroxidation & [77] \\
\hline & Common bean & Photosynthetic rate, growth & [78] \\
\hline & Tomato & Lipid peroxidation, antioxidants & [79] \\
\hline & Tomato & Stomatal conductance, biomass production & [80] \\
\hline & Radish & Electrolyte leakage, chlorophyll content & [81] \\
\hline & Radish & miRNAs & [82] \\
\hline & Radish & Endogenous hormones levels, plant height & [83] \\
\hline & Maize & Antioxidant enzymes, lipid peroxidation & [77] \\
\hline \multirow{16}{*}{ Drought stress } & Lemmon grass & Growth, oil metabolism & [84] \\
\hline & Alfalfa & Sugar contents, amino acid accumulation & [85] \\
\hline & Arabidopsis & Membrane lipid composition & [86] \\
\hline & Arabidopsis & Photosystem II (PSII) photochemistry & [87] \\
\hline & Arabidopsis & PSII, chlorophyll contents & [88] \\
\hline & Arabidopsis & PSII photochemistry chlorophylls & [89] \\
\hline & Arabidopsis & Antioxidant enzymes & [90] \\
\hline & Arabidopsis & microRNA expressions & [91] \\
\hline & Arabidopsis & Transcriptome & [92] \\
\hline & Arabidopsis & Hormones & [93] \\
\hline & Arabidopsis & Polyamine metabolism & [94] \\
\hline & Arabidopsis & Stomatal closure & [95] \\
\hline & Arabidopsis & $\mathrm{Na}+/ \mathrm{H}+$ antiporter TNHX1 & [96] \\
\hline & Arabidopsis & Chromatin status & [97] \\
\hline & Arabidopsis & Drought rhizogenesis & [98] \\
\hline & Arabidopsis & $\mathrm{H}_{2} \mathrm{O}_{2}$ contents, chlorophyll contents & [99] \\
\hline
\end{tabular}


Table 1. Cont.

\begin{tabular}{ccc}
\hline Abiotic Stress Condition & Plant/Crop Species & Key Parameters Studied \\
\hline & Brassica & Phytoremediation potential \\
\cline { 2 - 3 } & Cabbage & Growth and metabolisim \\
\cline { 2 - 3 } Heavy metal stress & Sunflower & Gaseous exchange, photosynthesis \\
\cline { 2 - 3 } & Peppermint, Cornmint & Oil quality \\
\cline { 2 - 3 } & Plants (in general) & Phenolic compounds \\
\cline { 2 - 3 } & Rapeseed & Proline contents, Cu levels \\
\hline & Rapeseed & Cadmium and lead levels \\
\hline
\end{tabular}

\section{Sensing Abiotic Stress in Plants}

Plants, during their lifetime, must choose priorities at various points for their survival based on the environmental cues they perceive. While downstream cellular signaling cascades and physiological responses after stress conditions have been well-explored, the understanding of how plants perceive signals is still debatable. Abiotic stresses are perceived mainly by sensory mechanisms that have the potential to translate physical and chemical environments created due to environmental cues such as low or high temperature, drought, salinity, etc., into a biological signal. This system has been well established in mammals. For example, in mammals heat is perceived by both the Transient Receptor Potential (TRP) ion channel family and neuron-based Twik-Related Potasium (TREK) channel family. Temperature elevation results in depolarization and induces the removal of corresponding neurons $[108,109]$. Thus, the signal is perceived by the transmembrane ion channel which converts the environmental signal to a cellular response such as changing membrane potential [110].

In plants, abiotic stress perception is less studied. While the perception mechanism is well-explored for some stresses, identification of sensing mechanism for others has been problematic. In fact, the criteria to define "abiotic stress sensors" have been unclear due to the lack of clear ligands [110]. Recently, in a study for the search of thermosensors in plants, $\mathrm{Vu}$, et al. [111] proposed three criteria to identify true heat sensor: (1) the condition (abiotic stress) must bring changes in structural properties or activity of the component; (2) these properties affect the downstream signaling cascades; and (3) changes in the properties or activity must lead to physio-morphological adaptations of plants in response to stress. Lamers, van der Meer and Testerink [110] further suggested that it must be the external environment that is sensed to distinguish stress perception from intracellular signaling processes. Here, we will discuss how different abiotic stresses are sensed by plants.

Temperature changes influence several biological processes and aspects of plant life such as root and shoot growth, yield, flowering, and resistance to pests [112]. Alteration in temperature changes the enzyme kinetics, protein structure and binding, protein folding, and membrane fluidity. In plants, two different mechanisms have been proposed for sensing temperature fluctuations, namely phytochromes for slight changes in ambient temperature and heat shock proteins (HSPs) for heat stress [110]. Here we will discuss more HSPs as we want to focus on heat stress. HSPs are a highly conserved family among various organisms [113]. Heat stress denatures water-soluble proteins resulting in their hydrophobic core being exposed. These hydrophobic regions, along with the hydrophobic regions of other proteins, aggregate together resulting in protein precipitation [110]. HSPs also have a hydrophobic region that is used to interact with such aggregated proteins [114-116]. After binding, heat shock factor (HSF) transcription factors are released which further binds to heat shock elements (HSE) to regulate transcription [117]. HSPs can also be induced by other stresses such as drought and salt [118]. However, reports suggest that for these stresses HSPs do not have a sensing role. Rather, they respond to these stresses through downstream signaling pathways [119]. 
As with heat, low temperature should also be sensed by plants in time as extremely low temperatures can form ice crystals which can cause cell death. The Open Stomata1 (OST1) earlier identified for its role in stomatal closure $[120,121]$ represents the key regulator in the cold signaling pathway in Arabidopsis [110]. Reports suggested that myristoylation of clade-E-Growth-Regulating2 (EGR2) by N-myristoyltransferase1 (NMT1) 30 min after cold treatment induces OST1 phosphorylation [122]. After cold perception, OST1 also phosphorylates the transcription factors inducer of CBF expression1 (ICE1) and Basic Transcription Factor3 (BTF3) inducing Cold-Regulated (COR) gene expression [121,123]. The cold-induced phosphorylation of OST1 is independent of abscisic acid (ABA) [121,124]. Thus, OST1 is a downstream target of cold than EGR2 and NMT1 and that the latter can be considered as potential candidates for cold sensors [110].

Plants also have a sophisticated mechanism for sensing drought. Published studies suggest that drought is sensed as a decrease in osmotic potential as water deficit condition results in osmotic stress. Therefore, drought sensors are often referred to as osmosensors [110]. For the first time, potential drought/osmosensors were identified during screening EMS-mutagenized Arabidopsis seedlings that were expressing aequorin in a study involving $\mathrm{Ca} 2+$ influx in response to sorbitol. The study resulted in the identification of a mutant line reduced hyperosmolality-induced $\left(\mathrm{Ca}^{2+}\right)$ increase1 (osca1; $\left.[125]\right)$. The mutant line showed a reduction in $\mathrm{Ca}^{2+}$ accumulation when subjected to sorbitol but not in response to $\mathrm{ABA}$ or $\mathrm{H}_{2} \mathrm{O}_{2}$. In silico analyses comprising phylogenetic studies showed that Arabidopsis has at least 15 homologs of OSCA1. Therefore, sensing hyperosmotic conditions could be regulated by a family of calcium channels [126].

Although salt resembles drought stress and is sensed in a similar mechanism by osmosensors, as both result in osmotic stress [38]. However, salt also causes ionic stress and, therefore, an additional sensing mechanism is required to sense the adversity by the ionic part. In this regard, the $\mathrm{Ca}^{2+}$-dependent SOS pathway is the main component for the exclusion of $\mathrm{Na}^{+}$. The key components of this pathway are SOS3 and associated SCaBP8 $\mathrm{Ca}^{2+}$ sensors, the SOS2 and SOS2-Like Protein Kinase5 (PKB5), and the SOS1 Na ${ }^{+} / \mathrm{H}^{+}$antiporter [127-130]. Quan, Lin et al. [130] reported $\mathrm{Ca}^{2+}$ spikes as quick as $10 \mathrm{~s}$ after sodium application which induced SOS3 and SCaBP8 that further activate SOS2. Afterward, SOS2 phosphorylates membrane-localized SOS1 which excludes $\mathrm{Na}^{+}$from the cell.

HM stress is another drastic stress that can threaten plant life. Like other abiotic stresses it initiates ROS and related signaling pathways. However, for any signal transduction pathway, signal perception represents the most important step to initiate a signal. Unfortunately, in the case of HMs, little is known about the perception mechanism due to limited studies on this aspect. The current literature suggests that they may be perceived by the plasma membrane proteins responsible for metal acquisition such as reductases and transporters [45]. However, deep studies focusing on HM perception mechanisms are needed to elaborate the activation of signaling cascades in response to HM.

\section{Molecular Aspects and Role of Biotechnological Tools}

The signals perceived after environmental stimuli are translated into a biological response. These responses are mainly mediated by genes and transcription factors which are also induced in response to these stimuli. In addition, these environmental factors result in the production of redox molecules such as ROS and RNS (reactive nitrogen species) $[4,131]$ which result in the activation of downstream signaling cascades involving the activation of genes that encode products (proteins, metabolites) which may help the plant to avoid or resist stress conditions. Environmental stress also shares a similar response towards different stresses. For example, many genes that are induced by drought also show a similar response to salt and low temperature [59]. Genes also show pleiotropy under several abiotic conditions. For example, genes that are induced during drought stress not only protecting cells from water deficit conditions but induce the production of key metabolic proteins that regulate signal transduction following drought stress [132-134]. Therefore, to understand the mechanisms associated with the perception of stress and a 
plant's response towards it, studying global changes in gene expression represents the most effective strategy to identify candidate genes involved in the regulation of stress conditions.

\subsection{RNA-Seq Mediated Transcriptome Analyses}

Since its development in the early 2000s RNA-seq has become a powerful tool in molecular biology. RNA-seq mediated transcriptome analyses are a useful and widely used tool to identify differentially expressed genes (DEGs) in response to environmental stimuli. The technique uses a combined in silico and in vivo approach and helps identify interesting candidate genes on a global scale. These candidate genes could be useful in dissecting the downstream signaling cascades under stress conditions. Several transcriptomic studies in response to various abiotic stresses in a range of species have been reported. Transcriptomic studies in response to heat stress in Brassica juncea [135] ryegrass [136], rice [137], Chinese cabbage [138], upland cotton (Gossypium hirsutum) [139], and maize [140] have been reported. Similarly, transcriptomic studies in response to cold stress have been reported in rice [141-143], maize [144-148], wheat [149-151] Camelia sinensis [152], Solanum lycopersicoides [153], Capsicum annum [154,155], and Jatropha curcas [156]. Drought-induced transcriptome have also been reported such as in maize [144,157], rice [158,159], turnips [160], poplars [161], European beech [162], chickpeas (Cicer arietinum) [163], potatoes (Solanum tuberosum) [164], wheat (Tricticum aestivum) [165], lentils (Lens culinaris Medikus) [166], and Korean aspen (Poplus davidiana) $[167,168]$. In response to salinity transcriptomic studies have been reported in oats [169], turnips [170], alfalfa [171], date palms [172], halophytic turf grass [173], halophyte Salicornia persica [174], Jatropha [175] etc. Those transcriptome data sets provide deep insights into the biological pathways and molecular mechanisms involved in the regulation of growth, development, cell death, signaling changes in response to abiotic stresses. Furthermore, the huge amount of data on the subject represents a valuable source for breeders to develop stress-tolerant varieties and strategic data mining from large and repetitive data sets and can lead to a better understanding of plant biochemistry and physiology for applications to crop improvement against abiotic stresses.

\subsection{The Role of CRISPR Technology in Abiotic Stress Tolerance}

Stress due to biotic factors such as plant pathogens is often specific to plant species, the type of the pathogens, and environmental conditions. However, abiotic stresses such as low or high temperature, soil moisture, heavy metals, salinity, or low and intense light are common throughout the world, limiting the growth and reproduction of every crop globally. Therefore, it is imperative to engineer crops with horizontal resistance against abiotic stresses. Although natural selection in wild plant species helped establish more generalized defenses against abiotic stresses through the course of co-evolution, human intervention, selective breeding for production and other quantitative traits have diluted the natural stress resistance of cultivated species. Mechanisms of incorporating abiotic stress tolerance for a long time include the classical breeding of crops with resistance traits against abiotic stresses. However, this is a time-consuming and species-specific technique. New methods include genetic engineering of crop plants for resistance against salinity, drought, and heat stress, with genes regulating key signaling pathways governing abiotic stress responses.

The introduction of gene(s) for the incorporation of abiotic stress tolerance in plants has been the hallmark of extensive research conducted for the past few decades. However, there are still certain limitations concerned with the classical methods of genetic engineering. Abiotic stress responses being highly diverse, and dynamic are often controlled by multiple genes spanning large quantitative trait loci (QTLs). Classical genetic engineering often involves the use of plasmids or cosmids with a limited capacity for carrying and ectopically expressing foreign genes in plants. Introducing foreign genes into plants for the alteration of certain traits often intervenes with other traits producing undesirable traits. On the other hand, the introduction of foreign genetic material to generate transgenic plants creates 
genetically modified plants/organisms (GMOs) and the public release and consumption of GMOs are strictly prohibited and or regulated via stringent policies in several countries.

The use of CRISPR/Cas9 for genome editing involves alteration in the original base pair arrangement within the genome of an organism. Hence, this does not involve the introduction of foreign genetic material, and the plants generated via this method are not generally considered GMOs. Simultaneous editing of multiple target genes is an important advantage of the CRISPR/Cas9 system [176,177].

Though CRISPR/Cas9 technology is relatively new, it has been regularly used in plant sciences after its debut in mouse genetics. A simple search on PubMed (NCBI) indicates that the number of studies reporting the use of CRISPR/Cas9 is very large, covering plant species ranging from the Model plant Arabidopsis to crops such as tobacco, sorghum, soybean, tomato, potato, rice, wheat, maize, apple, banana, and poplar [178-183].

Halophytes have natural salt tolerance thanks to a repertoire of genes regulating salt stress via different pathways. Several genes from halophytes have been ectopically expressed in other plant species for successful engineering of salt tolerance [see Table 1 in [184]]. A large number of genes have been identified from different plant species that regulate salt stress responses at various levels. These include genes involved in photorespiration, proline accumulation, ion transportation, compartmentalization, phytohormone regulation, ion acquisition in the roots, $\mathrm{Na}+\mathrm{K}+$ acquisition and homeostasis, and others [184]. Most of these genes have been used to generate transgenic plants with significant salt-stress tolerance and such information can be used to improve salinity tolerance in crops via targeted genome editing using the CRISPR/Cas system. CRISPR/Cas system has been extensively used to incorporate desirable traits in grain crops especially rice [185]. Ref. [186] incorporated enhanced salinity tolerance in rice via mutagenesis of the OsRR22 gene via CRISPR/Cas9 technology. Ref. [187] reported CRISPR/cas9 mediated editing of the OsDST gene for drought and salt tolerance in the indica rice cultivar MTU1010. Similarly, CRISPR/Cas9 technology has also been used for the eluviation of drought stress tolerance.

The list of genes edited via CRISPR/Cas9 technology for engineering abiotic stress tolerance in various plant species is provided in Table 2. However, the actual number of studies utilizing CRISPR technology is significantly higher and rapidly increasing. The Open Stomata 2 (OST2) gene has been genetically edited via CRISPR to incorporate drought stress tolerance in Arabidopsis thaliana [188]. Similarly, microRNA editing via CRISPR has also been successfully employed in plants. Ref. [189] edited miR169a and MIR827a for drought stress tolerance in Arabidopsis thaliana. Genes encoding the ABAresponsive element-binding protein (AREB) are well known for their role in regulating ABA-dependent drought stress responses. Roca Paixao, et al. [190] performed CRISPR mediated genetic editing of the Arabidopsis AREB1 for drought stress tolerance. Other examples of genes edited via CRISPR technology in different plant species for controlling drought stress tolerance include the ARGOS8 [191], AGO18A and AGO18B [192], MS8 [193], DMC1 [194], ZB7 [195], DREB and ERF3 [196], LOX and UBIL1 [197], MS1 [198], MS45 [199] in maize and wheat plants.

The CRISPR/Cas9 technology has perhaps been most extensively used for the improvement of rice crops. A plethora of genes have been genetically edited via this technology in rice for conferring resistance to abiotic stresses such as salt stress $[186,187,200]$, cold stress [201,202], and stress due to heavy metal accumulation in the soil [203-205]. In short, the list of plant genes and functions targeted for editing via CRISPR technology is now very large and is still growing. Further enhancements and modifications in the technique are now making it easy to target specific genes and make major to minor genetic adjustments without introducing foreign genetic material. 
Table 2. List of genes edited via CRISPR/Cas9 technology in various species.

\begin{tabular}{|c|c|c|c|}
\hline Plant/Crop & Genes Targeted & Associated Function(s) & Reference \\
\hline \multirow{4}{*}{ Arabidopsis } & Open Stomata 2 (OST2) & Drought stress tolerance & [188] \\
\hline & miR169a and MIR827a & Drought stress tolerance & [189] \\
\hline & $\begin{array}{c}\text { Vacuolar } \\
\mathrm{H}^{+} \text {-pyrophosphatase } \\
(A V P 1)\end{array}$ & Drought stress tolerance & [206] \\
\hline & $\begin{array}{c}\text { ABA-Responsive } \\
\text { element-binding protein } \\
1(A R E B 1)\end{array}$ & Drought stress tolerance & [190] \\
\hline Maize and wheat & $\begin{array}{c}\text { ARGOS8 } \\
\text { AGO18A and AGO18B } \\
\text { MS8 } \\
\text { DMC1 } \\
\text { ZB7 } \\
\text { DREB2 and ERF3 } \\
\text { LOX2 and UBIL1 } \\
\text { MS1 } \\
\alpha-G L I A D I N S \\
\text { MS45 }\end{array}$ & $\begin{array}{l}\text { Drought stress tolerance and } \\
\text { others }\end{array}$ & $\begin{array}{l}{[191]} \\
{[192]} \\
{[193]} \\
{[194]} \\
{[195]} \\
{[196]} \\
{[197]} \\
{[198]} \\
{[199]}\end{array}$ \\
\hline \multirow{15}{*}{ Rice } & OSRR22 & Salinity tolerance & [186] \\
\hline & OSDST & Salt tolerance & [187] \\
\hline & OsCTB $4 a$ & Booting stage cold tolerance & [207] \\
\hline & OsCOLD1 & cold tolerance & [201] \\
\hline & $\begin{array}{l}\text { OsMODD } \\
\text { OsTT1 }\end{array}$ & $\begin{array}{l}\text { Drought tolerance } \\
\text { Thermotolerance }\end{array}$ & $\begin{array}{l}{[208]} \\
{[209]}\end{array}$ \\
\hline & OsSIT1 & Salt tolerance & [200] \\
\hline & BBS1 & Drought stress & [210] \\
\hline & $(\mathrm{OsPT} 4)$ & $\begin{array}{c}\text { Help in uptaking arsenic (As) } \\
\text { from soil }\end{array}$ & [203] \\
\hline & OsNAC14 & Drought tolerance & [211] \\
\hline & $\begin{array}{c}\text { Oryza sativa annexins } 3 \\
\text { (OsANN3) }\end{array}$ & cold tolerance & [202] \\
\hline & OsNRAM5 & Uptake of cadmium from soil & [204] \\
\hline & OsHAK1 & $\begin{array}{l}\text { Uptake of radioactive Cs } \\
\text { (137Cs+) from soil in rice plant }\end{array}$ & [205] \\
\hline & $\begin{array}{l}\text { ABA-activated protein } \\
\text { kinase } 2 \text { of } S n R K 2 \text { gene } \\
\text { family (SAPK2) }\end{array}$ & Drought and salinity tolerance & [212] \\
\hline & $\begin{array}{c}\text { Oryza sativa } \\
\text { 9-cisepoxycarotenoid } \\
\text { dioxygenase }(O s N C E D)\end{array}$ & Drought and salinity tolerance & [213] \\
\hline & OsRAV2 & Salinity tolerance & [214] \\
\hline Tomato & $\begin{array}{c}\text { Mitogen-activated } \\
\text { protein kinase } 3 \\
\text { (SIMAPK3) in Solanum } \\
\text { lycopersicum }\end{array}$ & Drought tolerance & [212] \\
\hline
\end{tabular}

\section{Conclusions}

This study aimed to highlight the importance of abiotic stresses in plants and compile the latest knowledge on how a plant senses stress conditions which are primarily critical 
for signal initiation and, hence, downstream activation of stress pathways in addition to plant responses to various environmental stresses at the molecular level. In the second part of the paper, we described various molecular aspects and biotechnological tools such as transcriptomics, and gene editing techniques such as CRISPR that have been employed so far to improve the resilience of crops against abiotic stresses.

Changes in environmental conditions often cause irreparable damages to plants/crops, significantly reducing their yield. Figure 1 summarizes plants' response to various abiotic stresses and the role of modern biotechnological tools in the generation of resistant cultivars. Temperature stresses such as heat and cold, along with drought and salinity, are among the most important environmental factors that threaten agriculture production. The level of damage is determined by the severity and frequency of stress conditions. Plants, being sedentary in nature and unable to move for favorable conditions, have developed a sophisticated mechanism to cope with these adversities. To give a well-articulated response to stress, plants rely on the perception mechanism through which they induce a downstream signaling cascade to prepare their response. Biotechnological tools such as RNA-seq have made it easy to identify global changes in gene expression in response to environmental stimuli and identify candidate genes. Validation of these candidates through a functional genomics approach will help the breeders to develop stress-tolerant cultivars without bias. Recently, the gene-editing tool CRISPR Cas9 represents an appealing choice to develop stress-resistant cultivars without the introduction of external genes. Despite rapid growth in scientific studies involving advanced technologies, there is still room for improvements in the use of these techniques to avoid the associated undesirable traits.

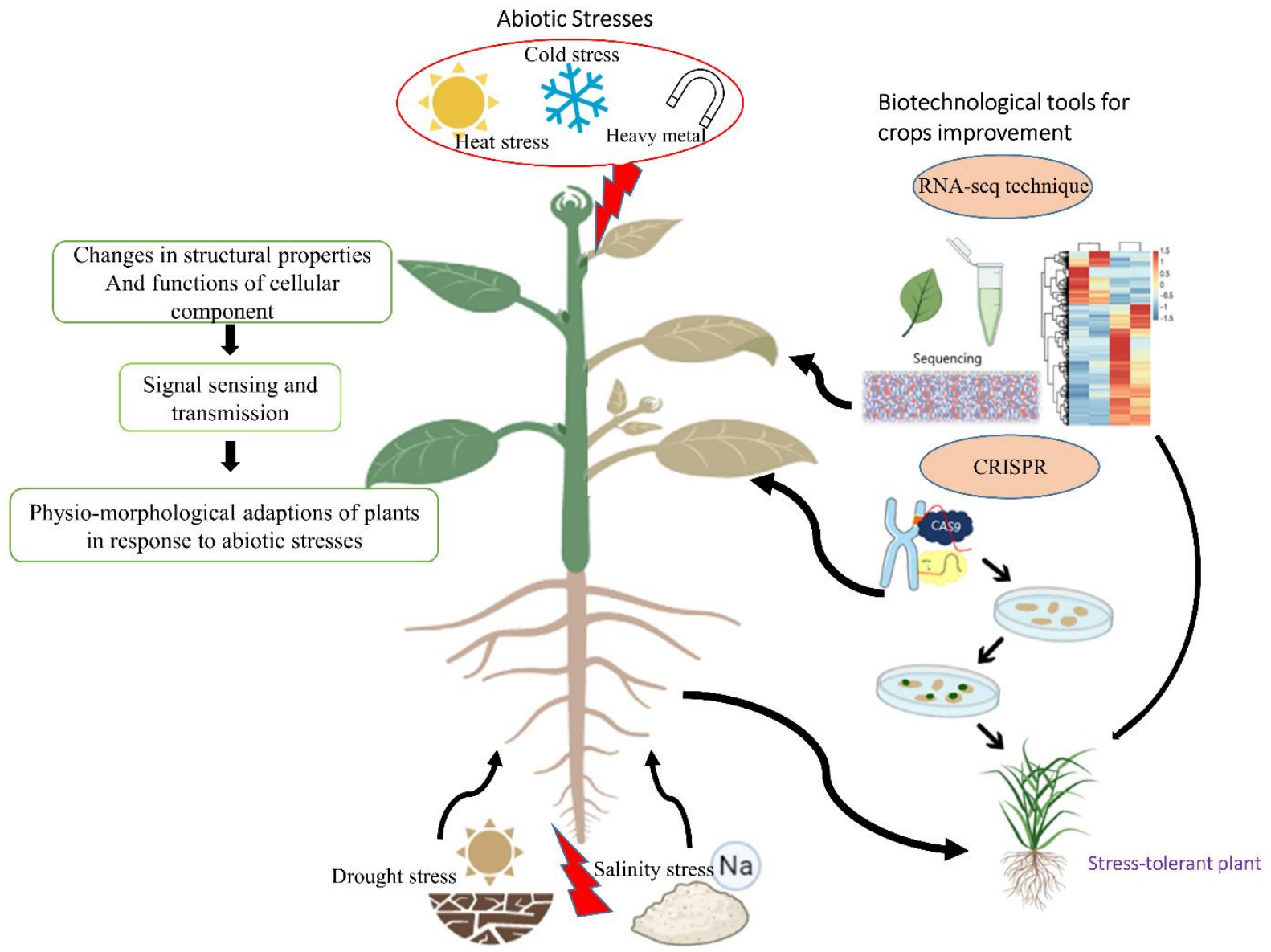

Figure 1. Schematic presentation of major abiotic stresses and biotechnological tools to help plants to resist these stress conditions. 


\section{Future Perspectives}

The current outbreak of COVID-19 on a global scale, killing more than four million people globally, has forced scientists to start thinking about "global threats to humanity" in a whole new way. The Geneva Science and Diplomacy Anticipator (GESDA), created in late 2019, presented their post-COVID report in April of 2019, planning for a summit to bring together hundreds of United Nations (UN) officials, academics, noble laureates, diplomats, advocacy groups, universities, scientists, and others to highlight that the COVID-19 pandemic has provided scientists with a whole new platform and an example of how advanced planning could help counter and head-off other future crises or threats to humanity such as climate change.

Although diseases or pandemics such as COVID-19 are acute problems that occur after a long period of time, abiotic stresses to plants have been a global phenomenon since ancient times and have silently become a chronic problem. Abiotic stresses, therefore, have had significant contribution in shaping various civilizations. The future holds unlimited resources in terms of science, technology, and innovation (STI) to solve these global problems. Traditional breeding approaches to improve abiotic stress tolerance have largely failed due to the multigenic nature of stress tolerance and the long time required in these approaches. As described above, molecular techniques have been developed over the last few decades to understand the mechanisms governing stress tolerance at the gene-level. The discovery of microRNAs (miRNAs) regulating gene expression, post-translational modifications of proteins to accommodate more complex functions for the same set of gene(s), has proved to be critical points in the understanding of abiotic stress tolerance. With the addition of CRISPR technology, scientists now have a greater and faster chance of incorporating abiotic stress tolerance in crop plants. Since its discovery, basic scientists have been developing new CRISPR-based tools and modifications which the translational researchers should put to use, revealing new insights into abiotic stress and their management.

Author Contributions: Conceptualization, Q.M.I., and N.F.; resources, B.-W.Y.; writing-original draft preparation, Q.M.I. and N.F.; writing—review and editing, A.H., and B.-G.M.; funding acquisition, B.-W.Y. All authors have read and agreed to the published version of the manuscript.

Funding: This research was supported by Kyungpook National University Development Project Research Fund, 2018 and the Basic Science Research Program through the National Research Foundation of Korea (NRF) funded by the Ministry of Education (Grant number 2020R1I1A3073247).

Data Availability Statement: Data sharing not applicable.

Acknowledgments: This research was supported by the Kyungpook National University Development Project Research Fund, 2018.

Conflicts of Interest: The authors declare no conflict of interest.

\section{References}

1. Boyer, J.S. Plant productivity and environment. Science 1982, 218, 443-448. [CrossRef]

2. Wu, G.; Zhang, C.A.; Chu, L.Y.; Shao, H.B. Responses of higher plants to abiotic stresses and agricultural sustainable development. J. Plant Interact. 2007, 2, 135-147. [CrossRef]

3. Deng, X.P.; Shan, L.; Inanaga, S.; Inoue, M. Water-saving approaches for improving wheat production. J. Sci. Food Agr. 2005, 85, 1379-1388. [CrossRef]

4. Cramer, G.R.; Urano, K.; Delrot, S.; Pezzotti, M.; Shinozaki, K. Effects of abiotic stress on plants: A systems biology perspective. BMC Plant Biol. 2011, 11, 163. [CrossRef] [PubMed]

5. Jones, P.D.; New, M.; Parker, D.E.; Martin, S.; Rigor, I.G. Surface air temperature and its changes over the past 150 years. Rev. Geophys. 1999, 37, 173-199. [CrossRef]

6. Wahid, A.; Gelani, S.; Ashraf, M.; Foolad, M.R. Heat tolerance in plants: An overview. Environ. Exp. Bot. 2007, 61, 199-223. [CrossRef]

7. Stratonovitch, P.; Semenov, M.A. Heat tolerance around flowering in wheat identified as a key trait for increased yield potential in Europe under climate change. J. Exp. Bot. 2015, 66, 3599-3609. [CrossRef]

8. Kotak, S.; Larkindale, J.; Lee, U.; von Koskull-Doring, P.; Vierling, E.; Scharf, K.D. Complexity of the heat stress response in plants. Curr. Opin. Plant. Biol. 2007, 10, 310-316. [CrossRef] 
9. Hall, A.E. Crop Responses to Environment; CRC press: Boca Raton, FL, USA, 2000.

10. Porter, J.R. Rising temperatures are likely to reduce crop yields. Nature 2005, 436, 174. [CrossRef]

11. Solanke, A.U.; Sharma, A.K. Signal transduction during cold stress in plants. Physiol. Mol. Biol. Plants 2008, 14, 69-79. [CrossRef]

12. Eremina, M.; Rozhon, W.; Poppenberger, B. Hormonal control of cold stress responses in plants. Cell. Mol. Life Sci. 2016, 73, 797-810. [CrossRef]

13. Ruelland, E.; Vaultier, M.N.; Zachowski, A.; Hurry, V. Cold Signalling and Cold Acclimation in Plants. Adv. Bot. Res. 2009, 49, 35-150. [CrossRef]

14. Wang, X.; Li, W.; Li, M.; Welti, R. Profiling lipid changes in plant response to low temperatures. Physiol. Plant. 2006, 126, 90-96. [CrossRef]

15. Uemura, M.; Joseph, R.A.; Steponkus, P.L. Cold acclimation of Arabidopsis thaliana (effect on plasma membrane lipid composition and freeze-induced lesions). Plant Physiol. 1995, 109, 15-30. [CrossRef]

16. Fahad, S.; Bajwa, A.A.; Nazir, U.; Anjum, S.A.; Farooq, A.; Zohaib, A.; Sadia, S.; Nasim, W.; Adkins, S.; Saud, S. Crop production under drought and heat stress: Plant responses and management options. Front. Plant Sci. 2017, 8, 1147. [CrossRef]

17. Lobell, D.B.; Schlenker, W.; Costa-Roberts, J. Climate trends and global crop production since 1980. Science 2011, 333, 616-620. [CrossRef] [PubMed]

18. Daryanto, S.; Wang, L.; Jacinthe, P.-A. Global synthesis of drought effects on maize and wheat production. PLoS ONE 2016, 11, e0156362. [CrossRef] [PubMed]

19. Barnabás, B.; Jäger, K.; Fehér, A. The effect of drought and heat stress on reproductive processes in cereals. Plant Cell Environ. 2008, 31, 11-38. [CrossRef]

20. Kaya, M.D.; Okçu, G.; Atak, M.; Cıkılı, Y.; Kolsarıcı, Ö. Seed treatments to overcome salt and drought stress during germination in sunflower (Helianthus annuus L.). Eur. J. Agron. 2006, 24, 291-295. [CrossRef]

21. Farooq, M.; Wahid, A.; Kobayashi, N.; Fujita, D.; Basra, S.A. Plant drought stress: Effects, mechanisms and management. Agron. Sustain. Dev. 2009, 29, 185-212. [CrossRef]

22. Okçu, G.; Kaya, M.D.; Atak, M. Effects of salt and drought stresses on germination and seedling growth of pea (Pisum sativum L.). Turk. J. Agric. 2005, 29, 237-242.

23. Manickavelu, A.; Nadarajan, N.; Ganesh, S.; Gnanamalar, R.; Babu, R.C. Drought tolerance in rice: Morphological and molecular genetic consideration. Plant. Growth Regul. 2006, 50, 121-138. [CrossRef]

24. Rucker, K.; Kvien, C.; Holbrook, C.; Hook, J. Identification of peanut genotypes with improved drought avoidance traits. Peanut Sci. 1995, 22, 14-18. [CrossRef]

25. Zhao, T.-J.; Sun, S.; Liu, Y.; Liu, J.-M.; Liu, Q.; Yan, Y.-B.; Zhou, H.-M. Regulating the drought-responsive element (DRE)-mediated signaling pathway by synergic functions of trans-active and trans-inactive DRE binding factors in Brassica napus. J. Biol. Chem. 2006, 281, 10752-10759. [CrossRef]

26. Yadav, R.S.; Hash, C.; Bidinger, F.; Devos, K.; Howarth, C.J. Genomic regions associated with grain yield and aspects of postflowering drought tolerance in pearl millet across stress environments and tester background. Euphytica 2004, 136, 265-277. [CrossRef]

27. DaMatta, F.M.; Ramalho, J.D.C. Impacts of drought and temperature stress on coffee physiology and production: A review. Braz. J. Plant Physiol. 2006, 18, 55-81. [CrossRef]

28. Franchini, J.C.; Debiasi, H.; Sacoman, A.; Nepomuceno, A.L.; Farias, J.R.B. Manejo do solo Para Redução das Perdas de Produtividade Pela Seca; Embrapa Soja Londrina: Londrina, Brazil, 2009.

29. Turner, N.C.; Wright, G.C.; Siddique, K. Adaptation of grain legumes (pulses) to water-limited environments. Adv. Agron. 2001, 71, 193-231.

30. Shannon, M.C. Adaptation of plants to salinity. Adv. Agron. 1997, 60, 75-120.

31. Isayenkov, S. Physiological and molecular aspects of salt stress in plants. Cytol. Genet. 2012, 46, 302-318. [CrossRef]

32. Ashraf, M.; Wu, L. Breeding for salinity tolerance in plants. Crit. Rev. Plant Sci. 1994, 13, 17-42. [CrossRef]

33. Marschner, H. Marschner's Mineral Nutrition of Higher Plants; Academic Press: London, UK, 2011.

34. Levitt, J. Responses of Plants to Environmental Stress, Volume 1: Chilling, Freezing, and High Temperature Stresses; Academic Press: London, UK, 1980.

35. Munns, R.; Termaat, A. Whole-plant responses to salinity. Funct. Plant Biol. 1986, 13, 143-160. [CrossRef]

36. Shannon, M.C.; Grieve, C.M. Tolerance of vegetable crops to salinity. Sci Hortic. 1999, 78, 5-38. [CrossRef]

37. Munns, R.; Passioura, J. Hydraulic resistance of plants. III. Effects of NaCl in barley and lupin. Funct. Plant Biol. 1984, 11, 351-359. [CrossRef]

38. Munns, R.; Tester, M. Mechanisms of salinity tolerance. Annu. Rev. Plant Biol. 2008, 59, 651-681. [CrossRef]

39. Roy, S.J.; Negrão, S.; Tester, M. Salt resistant crop plants. Curr. Opin. Biotechnol. 2014, 26, 115-124. [CrossRef]

40. Rajendran, K.; Tester, M.; Roy, S.J. Quantifying the three main components of salinity tolerance in cereals. Plant Cell Environ. 2009, 32, 237-249. [CrossRef]

41. Ismail, A.M.; Heuer, S.; Thomson, M.J.; Wissuwa, M. Genetic and genomic approaches to develop rice germplasm for problem soils. Plant Mol. Biol. 2007, 65, 547-570. [CrossRef]

42. Maischak, H.; Zimmermann, M.R.; Felle, H.H.; Boland, W.; Mithöfer, A. Alamethicin-induced electrical long distance signaling in plants. Plant Signal. Behav. 2010, 5, 988-990. [CrossRef] 
43. Isayenkov, S.V.; Maathuis, F.J.M. Plant Salinity Stress: Many Unanswered Questions Remain. Front. Plant Sci. 2019, 10, 80. [CrossRef]

44. Ji, H.T.; Pardo, J.M.; Batelli, G.; Van Oosten, M.J.; Bressan, R.A.; Li, X. The Salt Overly Sensitive (SOS) Pathway: Established and Emerging Roles. Mol. Plant. 2013, 6, 275-286. [CrossRef]

45. Ghori, N.H.; Ghori, T.; Hayat, M.Q.; Imadi, S.R.; Gul, A.; Altay, V.; Ozturk, M. Heavy metal stress and responses in plants. Int. J. Env. Sci. Technol. 2019, 16, 1807-1828. [CrossRef]

46. Aydinalp, C.; Marinova, S. The effects of heavy metals on seed germination and plant growth on alfalfa plant (Medicago sativa). Bulg. J. Agric. Sci. 2009, 15, 347-350.

47. Dağhan, H.; Öztürk, M.; Hakeem, K.; Sabir, M.; Mermut, A. Soil pollution in Turkey and remediation methods. In Soil Remediation and Plants Prospects and Challenges; Hakeem, K.R., Sabir, M., Ozturk, M., Mermut, A.R., Eds.; Academic Press: Cambridge, MA, USA, 2015; pp. 287-312.

48. Hossain, M.A.; Piyatida, P.; da Silva, J.A.T.; Fujita, M. Molecular mechanism of heavy metal toxicity and tolerance in plants: Central role of glutathione in detoxification of reactive oxygen species and methylglyoxal and in heavy metal chelation. J. Bot. 2012, 2012, 872875. [CrossRef]

49. Rascio, N.; Navari-Izzo, F. Heavy metal hyperaccumulating plants: How and why do they do it? And what makes them so interesting? Plant Sci 2011, 180, 169-181. [CrossRef]

50. Shahid, M.; Khalid, S.; Abbas, G.; Shahid, N.; Nadeem, M.; Sabir, M.; Aslam, M.; Dumat, C. Heavy metal stress and crop productivity. In Crop Production and Global Environmental Issues; Springer: Berlin/Heidelberg, Germany, $2015 ;$ pp. 1-25.

51. Pinto, A.P.; Simoes, I.; Mota, A.M. Cadmium impact on root exudates of sorghum and maize plants: A speciation study. J. Plant Nutr. 2008, 31, 1746-1755. [CrossRef]

52. Sanita di Toppi, L.; Gabbrielli, R. Response to cadmium in higher plants. Environ. Exp. Bot. 1999, 41, 105-130. [CrossRef]

53. Saxena, I.; Shekhawat, G.S. Nitric oxide (NO) in alleviation of heavy metal induced phytotoxicity and its role in protein nitration Nitric Oxide 2013, 32, 13-20. [CrossRef]

54. Nabi, R.B.S.; Tayade, R.; Hussain, A.; Kulkarni, K.P.; Imran, Q.M.; Mun, B.G.; Yun, B.W. Nitric oxide regulates plant responses to drought, salinity, and heavy metal stress. Environ. Exp. Bot. 2019, 161, 120-133. [CrossRef]

55. Becher, M.; Talke, I.N.; Krall, L.; Kramer, U. Cross-species microarray transcript profiling reveals high constitutive expression of metal homeostasis genes in shoots of the zinc hyperaccumulator Arabidopsis halleri. Plant J. 2004, 37, 251-268. [CrossRef]

56. Pence, N.S.; Larsen, P.B.; Ebbs, S.D.; Letham, D.L.D.; Lasat, M.M.; Garvin, D.F.; Eide, D.; Kochian, L.V. The molecular physiology of heavy metal transport in the Zn/Cd hyperaccumulator Thlaspi caerulescens. Proc. Natl. Acad. Sci. USA 2000, 97, 4956-4960. [CrossRef]

57. Eren, E.; Arguello, J.M. Arabidopsis HMA2, a divalent heavy metal-transporting PIB-type ATPase, is involved in cytoplasmic Zn2+ homeostasis. Plant Physiol 2004, 136, 3712-3723. [CrossRef]

58. Drager, D.B.; Desbrosses-Fonrouge, A.G.; Krach, C.; Chardonnens, A.N.; Meyer, R.C.; Saumitou-Laprade, P.; Kramer, U. Two genes encoding Arabidopsis halleri MTP1 metal transport proteins co-segregate with zinc tolerance and account for high MTP1 transcript levels. Plant J. 2004, 39, 425-439. [CrossRef] [PubMed]

59. Chinnusamy, V.; Zhu, J.; Zhu, J.K. Cold stress regulation of gene expression in plants. Trends Plant Sci 2007, 12, 444-451. [CrossRef] [PubMed]

60. Panta, G.; Rieger, M.; Rowland, L. Effect of cold and drought stress on blueberry dehydrin accumulation. J. Hortic. Sci. Biotechnol. 2001, 76, 549-556.

61. Paredes, M.; Quiles, M.J. The effects of cold stress on photosynthesis in Hibiscus plants. PLoS ONE 2015, 10, e0137472. [CrossRef]

62. Hajihashemi, S.; Noedoost, F.; Geuns, J.; Djalovic, I.; Siddique, K.H. Effect of cold stress on photosynthetic traits, carbohydrates, morphology, and anatomy in nine cultivars of Stevia rebaudiana. Front. Plant Sci. 2018, 9, 1430. [CrossRef]

63. Li, X.; Cai, J.; Liu, F.; Dai, T.; Cao, W.; Jiang, D. Cold priming drives the sub-cellular antioxidant systems to protect photosynthetic electron transport against subsequent low temperature stress in winter wheat. Plant Physiol. Biochem. 2014, 82, 34-43. [CrossRef]

64. Wang, L.; Zhu, W.; Fang, L.; Sun, X.; Su, L.; Liang, Z.; Wang, N.; Londo, J.P.; Li, S.; Xin, H. Genome-wide identification of WRKY family genes and their response to cold stress in Vitis vinifera. BMC Plant Biol. 2014, 14, 103. [CrossRef]

65. Bae, M.S.; Cho, E.J.; Choi, E.Y.; Park, O.K. Analysis of the Arabidopsis nuclear proteome and its response to cold stress. Plant J. 2003, 36, 652-663. [CrossRef]

66. Chen, L.; Zhong, H.; Ren, F.; Guo, Q.-Q.; Hu, X.-P.; Li, X.-B. A novel cold-regulated gene, COR25, of Brassica napus is involved in plant response and tolerance to cold stress. Plant Cell Rep. 2011, 30, 463-471. [CrossRef] [PubMed]

67. Pan, Y.; Wang, W.; Zhao, X.; Zhu, L.; Fu, B.; Li, Z. DNA methylation alterations of rice in response to cold stress. Plant Omics J. 2011, 4, 364-369.

68. Gulen, H.; Eris, A. Effect of heat stress on peroxidase activity and total protein content in strawberry plants. Plant Sci. 2004, 166, 739-744. [CrossRef]

69. Murkowski, A. Heat stress and spermidine: Effect on chlorophyll fluorescence in tomato plants. Biol. Plant 2001, 44, 53-57. [CrossRef]

70. De Ronde, J.; Cress, W.; Krüger, G.; Strasser, R.; Van Staden, J. Photosynthetic response of transgenic soybean plants, containing an Arabidopsis P5CR gene, during heat and drought stress. J. Plant Physiol. 2004, 161, 1211-1224. [CrossRef] 
71. Cvikrová, M.; Gemperlová, L.; Dobrá, J.; Martincová, O.; Prásil, I.T.; Gubis, J.; Vanková, R. Effect of heat stress on polyamine metabolism in proline-over-producing tobacco plants. Plant Sci. 2012, 182, 49-58. [CrossRef]

72. Anfoka, G.; Moshe, A.; Fridman, L.; Amrani, L.; Rotem, O.; Kolot, M.; Zeidan, M.; Czosnek, H.; Gorovits, R. Tomato yellow leaf curl virus infection mitigates the heat stress response of plants grown at high temperatures. Sci. Rep. 2016, 6, 1-13.

73. Rizhsky, L.; Liang, H.; Shuman, J.; Shulaev, V.; Davletova, S.; Mittler, R. When Defense Pathways Collide. The Response of Arabidopsis to a Combination of Drought and Heat Stress. Plant Physiol. 2004, 134, 1683-1696. [CrossRef]

74. Zhang, Y.; Min, H.; Shi, C.; Xia, G.; Lai, Z. Transcriptome analysis of the role of autophagy in plant response to heat stress. PLoS ONE 2021, 16, e0247783.

75. Pan, T.; Sun, X.; Liu, Y.; Li, H.; Deng, G.; Lin, H.; Wang, S. Heat stress alters genome-wide profiles of circular RNAs in Arabidopsis. Plant Mol. Biol. 2018, 96, 217-229. [CrossRef] [PubMed]

76. Kim, J.H.; Lim, S.D.; Jang, C.S. Oryza sativa heat-induced RING finger protein 1 (OsHIRP1) positively regulates plant response to heat stress. Plant Mol. Biol. 2019, 99, 545-559. [CrossRef]

77. De Azevedo Neto, A.D.; Prisco, J.T.; Enéas-Filho, J.; de Abreu, C.E.B.; Gomes-Filho, E. Effect of salt stress on antioxidative enzymes and lipid peroxidation in leaves and roots of salt-tolerant and salt-sensitive maize genotypes. Environ. Exp. Bot. 2006, 56, 87-94. [CrossRef]

78. Stoeva, N.; Kaymakanova, M. Effect of salt stress on the growth and photosynthesis rate of bean plants (Phaseolus vulgaris L.). J. Cent. Eur. Agric. 2008, 9, 385-391.

79. Shalata, A.; Tal, M. The effect of salt stress on lipid peroxidation and antioxidants in the leaf of the cultivated tomato and its wild salt-tolerant relative Lycopersicon pennellii. Physiol. Plant 1998, 104, 169-174. [CrossRef]

80. Maggio, A.; Raimondi, G.; Martino, A.; De Pascale, S. Salt stress response in tomato beyond the salinity tolerance threshold. Environ. Exp. Bot. 2007, 59, 276-282. [CrossRef]

81. Yildirim, E.; Turan, M.; Donmez, M.F. Mitigation of salt stress in radish (Raphanus sativus L.) by plant growth promoting rhizobacteria. Roum. Biotechnol. Lett. 2008, 13, 3933-3943.

82. Sun, X.; Xu, L.; Wang, Y.; Yu, R.; Zhu, X.; Luo, X.; Gong, Y.; Wang, R.; Limera, C.; Zhang, K. Identification of novel and salt-responsive miRNAs to explore miRNA-mediated regulatory network of salt stress response in radish (Raphanus sativus L.). BMC Genom. 2015, 16, 1-16. [CrossRef]

83. Jasim, A.H.; Al Timmen, W.M.A.; Abid, A.S. Effect of salt stress on plant growth and free endogenous hormones of primed radish (Raphanus sativus L.) seeds with salicylic acid. Int. J. Chem. Tech. Res. 2016, 9, 339-346.

84. Singh-Sangwan, N.; Abad Farooqi, A.; Sangwan, R.S. Effect of drought stress on growth and essential oil metabolism in lemongrasses. New Phytol. 1994, 128, 173-179. [CrossRef]

85. Schubert, S.; Serraj, R.; Plies-Balzer, E.; Mengel, K. Effect of drought stress on growth, sugar concentrations and amino acid accumulation in N2-fixing alfalfa (Medicago sativa). J. Plant. Physiol. 1995, 146, 541-546. [CrossRef]

86. Gigon, A.; Matos, A.-R.; Laffray, D.; Zuily-Fodil, Y.; Pham-Thi, A.-T. Effect of drought stress on lipid metabolism in the leaves of Arabidopsis thaliana (ecotype Columbia). Ann. Bot. 2004, 94, 345-351. [CrossRef]

87. Sperdouli, I.; Moustakas, M. Spatio-temporal heterogeneity in Arabidopsis thaliana leaves under drought stress. Plant Biol. 2012, 14, 118-128. [CrossRef] [PubMed]

88. Chen, Y.E.; Liu, W.J.; Su, Y.Q.; Cui, J.M.; Zhang, Z.W.; Yuan, M.; Zhang, H.Y.; Yuan, S. Different response of photosystem II to short and long-term drought stress in Arabidopsis thaliana. Physiol. Plant 2016, 158, 225-235. [CrossRef] [PubMed]

89. Jung, S. Variation in antioxidant metabolism of young and mature leaves of Arabidopsis thaliana subjected to drought. Plant Sci. 2004, 166, 459-466. [CrossRef]

90. Dubey, A.K.; Kumar, N.; Kumar, A.; Ansari, M.A.; Ranjan, R.; Gautam, A.; Sahu, N.; Pandey, V.; Behera, S.K.; Mallick, S. Over-expression of CarMT gene modulates the physiological performance and antioxidant defense system to provide tolerance against drought stress in Arabidopsis thaliana L. Ecotoxicol. Environ. Saf. 2019, 171, 54-65. [CrossRef]

91. Shen, J.; Xing, T.; Yuan, H.; Liu, Z.; Jin, Z.; Zhang, L.; Pei, Y. Hydrogen sulfide improves drought tolerance in Arabidopsis thaliana by microRNA expressions. PLoS ONE 2013, 8, e77047. [CrossRef]

92. Rasheed, S.; Bashir, K.; Matsui, A.; Tanaka, M.; Seki, M. Transcriptomic analysis of soil-grown Arabidopsis thaliana roots and shoots in response to a drought stress. Front. Plant Sci. 2016, 7, 180. [CrossRef] [PubMed]

93. Huang, D.; Wu, W.; Abrams, S.R.; Cutler, A.J. The relationship of drought-related gene expression in Arabidopsis thaliana to hormonal and environmental factors. J. Exp. Bot. 2008, 59, 2991-3007. [CrossRef]

94. Alcázar, R.; Cuevas, J.C.; Patron, M.; Altabella, T.; Tiburcio, A.F. Abscisic acid modulates polyamine metabolism under water stress in Arabidopsis thaliana. Physiol. Plant 2006, 128, 448-455. [CrossRef]

95. Jin, Z.; Wang, Z.; Ma, Q.; Sun, L.; Zhang, L.; Liu, Z.; Liu, D.; Hao, X.; Pei, Y. Hydrogen sulfide mediates ion fluxes inducing stomatal closure in response to drought stress in Arabidopsis thaliana. Plant Soil 2017, 419, 141-152. [CrossRef]

96. Brini, F.; Hanin, M.; Mezghani, I.; Berkowitz, G.A.; Masmoudi, K. Overexpression of wheat Na+/H+ antiporter TNHX1 and H+-pyrophosphatase TVP1 improve salt-and drought-stress tolerance in Arabidopsis thaliana plants. J. Exp. Bot. 2007, 58, 301-308. [CrossRef] [PubMed]

97. Kim, J.-M.; To, T.K.; Ishida, J.; Matsui, A.; Kimura, H.; Seki, M. Transition of chromatin status during the process of recovery from drought stress in Arabidopsis thaliana. Plant Cell Physiol. 2012, 53, 847-856. [CrossRef] 
98. Vartanian, N.; Marcotte, L.; Giraudat, J. Drought rhizogenesis in Arabidopsis thaliana (differential responses of hormonal mutants). Plant Physiol. 1994, 104, 761-767. [CrossRef]

99. Niu, Y.; Wang, Y.; Li, P.; Zhang, F.; Liu, H.; Zheng, G. Drought stress induces oxidative stress and the antioxidant defense system in ascorbate-deficient vtc1 mutants of Arabidopsis thaliana. Acta Physiol. Plant 2013, 35, 1189-1200. [CrossRef]

100. Mourato, M.P.; Moreira, I.N.; Leitao, I.; Pinto, F.R.; Sales, J.R.; Martins, L.L. Effect of Heavy Metals in Plants of the Genus Brassica. Int. J. Mol. Sci. 2015, 16, 17975-17998. [CrossRef]

101. Pandey, N.; Sharma, C.P. Effect of heavy metals Co2+, Ni2+ and Cd2+ on growth and metabolism of cabbage. Plant Sci 2002, 163, 753-758. [CrossRef]

102. Bazzaz, F.; Carlson, R.W.; Rolfe, G. The effect of heavy metals on plants: Part I. Inhibition of gas exchange in sunflower by Pb, Cd, Ni and Tl. Environ. Pollut. (1970) 1974, 7, 241-246. [CrossRef]

103. Zheljazkov, V.D.; Nielsen, N.E. Effect of heavy metals on peppermint and cornmint. Plant Soil 1996, 178, 59-66. [CrossRef]

104. Del Rio, M.; Font, R.; De Haro, A. Heavy metal uptake by Brassica species growing in the polluted soils of Aznalcollar (Southern Spain). Fresenius Environ. Bull. 2004, 13, 1439-1443.

105. Alobaidi, K.H.; Bashmakova, E.B.; Kholodova, V.P. Response of two Brassica species to the toxic effect of different copper concentration. J. Environ. Prot. 2015, 6, 719-725. [CrossRef]

106. Cao, X.; Wang, X.; Tong, W.; Gurajala, H.K.; Lu, M.; Hamid, Y.; Feng, Y.; He, Z.; Yang, X. Distribution, availability and translocation of heavy metals in soil-oilseed rape (Brassica napus L.) system related to soil properties. Environ. Pollut. 2019, 252, 733-741. [CrossRef] [PubMed]

107. Solhi, M.; Hajabbasi, M. Heavy metals extraction potential of sunflower (Helianthus annuus) and canola (Brassica napus). Casp. J. Environ. Sci. 2005, 3, 35-42.

108. Voets, T.; Droogmans, G.; Wissenbach, U.; Janssens, A.; Flockerzi, V.; Nilius, B. The principle of temperature-dependent gating in cold- and heat-sensitive TRP channels. Nature 2004, 430, 748-754. [CrossRef] [PubMed]

109. Viatchenko-Karpinski, V.; Ling, J.; Gu, J.G. Characterization of temperature-sensitive leak K+ currents and expression of TRAAK, TREK-1, and TREK2 channels in dorsal root ganglion neurons of rats. Mol. Brain 2018, 11, 1-9. [CrossRef]

110. Lamers, J.; van der Meer, T.; Testerink, C. How Plants Sense and Respond to Stressful Environments(1)([OPEN]). Plant Physiol. 2020, 182, 1624-1635. [CrossRef] [PubMed]

111. Vu, L.D.; Gevaert, K.; De Smet, I. Feeling the Heat: Searching for Plant Thermosensors. Trends Plant. Sci. 2019, $24,210-219$. [CrossRef]

112. Quint, M.; Delker, C.; Franklin, K.A.; Wigge, P.A.; Halliday, K.J.; van Zanten, M. Molecular and genetic control of plant thermomorphogenesis. Nat. Plants 2016, 2, 15190. [CrossRef]

113. Schlesinger, M.J. Heal shock proteins. J. Biol. Chem. 1990, 265, 12111-12114. [CrossRef]

114. Yamamoto, M.; Takahashi, Y.; Inano, K.; Horigome, T.; Sugano, H. Characterization of the Hydrophobic Region of Heat-Shock Protein-90. J. Biochem. 1991, 110, 141-145. [CrossRef]

115. Benarroch, E.E. Heat shock proteins Multiple neuroprotective functions and implications for neurologic disease. Neurology 2011, 76, 660-667. [CrossRef]

116. Oroz, J.; Kim, J.H.; Chang, B.J.; Zweckstetter, M. Mechanistic basis for the recognition of a misfolded protein by the molecular chaperone Hsp90. Nat. Struct. Mol. Biol. 2017, 24, 407-413. [CrossRef]

117. Akerfelt, M.; Morimoto, R.I.; Sistonen, L. Heat shock factors: Integrators of cell stress, development and lifespan. Nat. Rev. Mol. Cell Biol. 2010, 11, 545-555. [CrossRef]

118. Liu, H.C.; Liao, H.T.; Charng, Y.Y. The role of class A1 heat shock factors (HSFA1s) in response to heat and other stresses in Arabidopsis. Plant Cell Environ. 2011, 34, 738-751. [CrossRef]

119. Yoshida, T.; Sakuma, Y.; Todaka, D.; Maruyama, K.; Qin, F.; Mizoi, J.; Kidokoro, S.; Fujita, Y.; Shinozaki, K.; Yamaguchi-Shinozaki, K. Functional analysis of an Arabidopsis heat-shock transcription factor HsfA3 in the transcriptional cascade downstream of the DREB2A stress-regulatory system. Biochem. Biophys. Res. Commun. 2008, 368, 515-521. [CrossRef]

120. Mustilli, A.-C.; Merlot, S.; Vavasseur, A.; Fenzi, F.; Giraudat, J. Arabidopsis OST1 protein kinase mediates the regulation of stomatal aperture by abscisic acid and acts upstream of reactive oxygen species production. Plant Cell 2002, 14, 3089-3099. [CrossRef] [PubMed]

121. Ding, Y.; Li, H.; Zhang, X.; Xie, Q.; Gong, Z.; Yang, S. OST1 kinase modulates freezing tolerance by enhancing ICE1 stability in Arabidopsis. Dev. Cell 2015, 32, 278-289. [CrossRef] [PubMed]

122. Ding, Y.; Lv, J.; Shi, Y.; Gao, J.; Hua, J.; Song, C.; Gong, Z.; Yang, S. EGR 2 phosphatase regulates OST 1 kinase activity and freezing tolerance in Arabidopsis. EMBO J. 2019, 38, e99819. [CrossRef] [PubMed]

123. Ding, Y.; Jia, Y.; Shi, Y.; Zhang, X.; Song, C.; Gong, Z.; Yang, S. OST 1-mediated BTF 3L phosphorylation positively regulates CBF s during plant cold responses. EMBO J. 2018, 37, e98228. [CrossRef] [PubMed]

124. Merlot, S.; Mustilli, A.C.; Genty, B.; North, H.; Lefebvre, V.; Sotta, B.; Vavasseur, A.; Giraudat, J. Use of infrared thermal imaging to isolate Arabidopsis mutants defective in stomatal regulation. Plant J. 2002, 30, 601-609. [CrossRef]

125. Yuan, F.; Yang, H.; Xue, Y.; Kong, D.; Ye, R.; Li, C.; Zhang, J.; Theprungsirikul, L.; Shrift, T.; Krichilsky, B. OSCA1 mediates osmotic-stress-evoked $\mathrm{Ca}^{2+}$ increases vital for osmosensing in Arabidopsis. Nature 2014, 514, 367-371. [CrossRef]

126. Liu, X.; Wang, J.; Sun, L. Structure of the hyperosmolality-gated calcium-permeable channel OSCA1.2. Nat. Commun. 2018, 9, 1-9. [CrossRef] 
127. Liu, J.; Zhu, J.-K. An Arabidopsis mutant that requires increased calcium for potassium nutrition and salt tolerance. Proc. Natl. Acad. Sci. USA 1997, 94, 14960-14964. [CrossRef]

128. Liu, J.; Zhu, J.-K. A calcium sensor homolog required for plant salt tolerance. Science 1998, 280, 1943-1945. [CrossRef] [PubMed]

129. Shi, H.; Quintero, F.J.; Pardo, J.M.; Zhu, J.-K. The putative plasma membrane Na+/H+ antiporter SOS1 controls long-distance $\mathrm{Na}+$ transport in plants. Plant Cell 2002, 14, 465-477. [CrossRef] [PubMed]

130. Quan, R.; Lin, H.; Mendoza, I.; Zhang, Y.; Cao, W.; Yang, Y.; Shang, M.; Chen, S.; Pardo, J.M.; Guo, Y. SCABP8/CBL10, a putative calcium sensor, interacts with the protein kinase SOS2 to protect Arabidopsis shoots from salt stress. Plant Cell 2007, 19, 1415-1431. [CrossRef] [PubMed]

131. Lindermayr, C. Crosstalk between reactive oxygen species and nitric oxide in plants: Key role of S-nitrosoglutathione reductase. Free Radic. Biol. Med. 2018, 122, 110-115. [CrossRef]

132. Yamaguchi-Shinozaki, K. Biological mechanisms of drought stress response. JIRCAS Work Rep. 2002, 23, 1-8.

133. Shinozaki, K.; Yamaguchi-Shinozaki, K.; Seki, M. Regulatory network of gene expression in the drought and cold stress responses. Curr. Opin. Plant Biol. 2003, 6, 410-417. [CrossRef]

134. Rudrabhatla, P.; Rajasekharan, R. Developmentally regulated dual-specificity kinase from peanut that is induced by abiotic stresses. Plant Physiol. 2002, 130, 380-390. [CrossRef]

135. Bhardwaj, A.R.; Joshi, G.; Kukreja, B.; Malik, V.; Arora, P.; Pandey, R.; Shukla, R.N.; Bankar, K.G.; Katiyar-Agarwal, S.; Goel, S. Global insights into high temperature and drought stress regulated genes by RNA-Seq in economically important oilseed crop Brassica juncea. BMC Plant Biol. 2015, 15, 9. [CrossRef]

136. Wang, Y.; Dai, Y.; Tao, X.; Wang, J.-Z.; Cheng, H.-Y.; Yang, H.; Ma, X.-R. Heat shock factor genes of tall fescue and perennial ryegrass in response to temperature stress by RNA-Seq analysis. Front. Plant Sci. 2016, 6, 1226. [CrossRef]

137. Cohen, S.P.; Liu, H.; Argueso, C.T.; Pereira, A.; Vera Cruz, C.; Verdier, V.; Leach, J.E. RNA-Seq analysis reveals insight into enhanced rice Xa7-mediated bacterial blight resistance at high temperature. PLoS ONE 2017, 12, e0187625. [CrossRef]

138. Song, X.; Liu, G.; Huang, Z.; Duan, W.; Tan, H.; Li, Y.; Hou, X. Temperature expression patterns of genes and their coexpression with LncRNAs revealed by RNA-Seq in non-heading Chinese cabbage. BMC Genom. 2016, 17, 297. [CrossRef]

139. Bowman, M.J.; Park, W.; Bauer, P.J.; Udall, J.A.; Page, J.T.; Raney, J.; Scheffler, B.E.; Jones, D.C.; Campbell, B.T. RNA-Seq transcriptome profiling of upland cotton (Gossypium hirsutum L.) root tissue under water-deficit stress. PLoS ONE 2013, 8, e82634. [CrossRef] [PubMed]

140. Shi, J.; Yan, B.; Lou, X.; Ma, H.; Ruan, S. Comparative transcriptome analysis reveals the transcriptional alterations in heat-resistant and heat-sensitive sweet maize (Zea mays L.) varieties under heat stress. BMC Plant Biol. 2017, 17, 26. [CrossRef] [PubMed]

141. Shen, C.; Li, D.; He, R.; Fang, Z.; Xia, Y.; Gao, J.; Shen, H.; Cao, M. Comparative transcriptome analysis of RNA-seq data for cold-tolerant and cold-sensitive rice genotypes under cold stress. J. Plant Biol. 2014, 57, 337-348. [CrossRef]

142. Guan, S.; Xu, Q.; Ma, D.; Zhang, W.; Xu, Z.; Zhao, M.; Guo, Z. Transcriptomics profiling in response to cold stress in cultivated rice and weedy rice. Gene 2019, 685, 96-105. [CrossRef]

143. Da Maia, L.C.; Cadore, P.R.; Benitez, L.C.; Danielowski, R.; Braga, E.J.; Fagundes, P.R.; Magalhães, A.M.; de Oliveira, A.C. Transcriptome profiling of rice seedlings under cold stress. Funct. Plant Biol. 2017, 44, 419-429. [CrossRef] [PubMed]

144. Lu, X.; Zhou, X.; Cao, Y.; Zhou, M.; McNeil, D.; Liang, S.; Yang, C. RNA-seq Analysis of Cold and Drought Responsive Transcriptomes of Zea mays ssp. mexicana L. Front. Plant Sci. 2017, 8, 136. [CrossRef]

145. Li, Z.; Hu, G.; Liu, X.; Zhou, Y.; Li, Y.; Zhang, X.; Yuan, X.; Zhang, Q.; Yang, D.; Wang, T. Transcriptome sequencing identified genes and gene ontologies associated with early freezing tolerance in maize. Front. Plant Sci. 2016, 7, 1477. [CrossRef]

146. Frey, F.P.; Pitz, M.; Schön, C.-C.; Hochholdinger, F. Transcriptomic diversity in seedling roots of European flint maize in response to cold. BMC Genom. 2020, 21, 300. [CrossRef] [PubMed]

147. Mao, J.; Yu, Y.; Yang, J.; Li, G.; Li, C.; Qi, X.; Wen, T.; Hu, J. Comparative transcriptome analysis of sweet corn seedlings under low-temperature stress. Crop. J. 2017, 5, 396-406. [CrossRef]

148. Fu, Y.-P.; Liang, Y.; Dai, Y.-T.; Yang, C.-T.; Duan, M.-Z.; Zhang, Z.; Hu, S.-N.; Zhang, Z.-W.; Li, Y. De novo sequencing and transcriptome analysis of Pleurotus eryngii subsp. tuoliensis (Bailinggu) mycelia in response to cold stimulation. Molecules 2016, 21, 560. [CrossRef]

149. Zhang, S.; Song, G.; Gao, J.; Li, Y.; Guo, D.; Fan, Q.; Sui, X.; Chu, X.; Huang, C.; Liu, J. Transcriptome characterization and differential expression analysis of cold-responsive genes in young spikes of common wheat. J. Biotechnol. 2014, 189, 48-57. [CrossRef]

150. Gulick, P.J.; Drouin, S.; Yu, Z.; Danyluk, J.; Poisson, G.; Monroy, A.F.; Sarhan, F. Transcriptome comparison of winter and spring wheat responding to low temperature. Genome 2005, 48, 913-923. [CrossRef]

151. Derakhshani, B.; Ayalew, H.; Mishina, K.; Tanaka, T.; Kawahara, Y.; Jafary, H.; Oono, Y. Comparative analysis of root transcriptome reveals candidate genes and expression divergence of homoeologous genes in response to water stress in wheat. Plants 2020, 9 , 596. [CrossRef]

152. Wang, X.-C.; Zhao, Q.-Y.; Ma, C.-L.; Zhang, Z.-H.; Cao, H.-L.; Kong, Y.-M.; Yue, C.; Hao, X.-Y.; Chen, L.; Ma, J.-Q. Global transcriptome profiles of Camellia sinensis during cold acclimation. BMC Genom. 2013, 14, 415. [CrossRef]

153. Chen, H.; Chen, X.; Chai, X.; Qiu, Y.; Gong, C.; Zhang, Z.; Wang, T.; Zhang, Y.; Li, J.; Wang, A. Effects of low temperature on mRNA and small RNA transcriptomes in Solanum lycopersicoides leaf revealed by RNA-Seq. Biochem. Biophys. Res. Commun. 2015, 464, 768-773. [CrossRef] 
154. Kang, W.-H.; Sim, Y.M.; Koo, N.; Nam, J.-Y.; Lee, J.; Kim, N.; Jang, H.; Kim, Y.-M.; Yeom, S.-I. Transcriptome profiling of abiotic responses to heat, cold, salt, and osmotic stress of Capsicum annuum L. Sci. Data 2020, 7, 1-7. [CrossRef]

155. Kong, X.-M.; Zhou, Q.; Luo, F.; Wei, B.-D.; Wang, Y.-J.; Sun, H.-J.; Zhao, Y.-B.; Ji, S.-J. Transcriptome analysis of harvested bell peppers (Capsicum annuum L.) in response to cold stress. Plant. Physiol. Biochem. 2019, 139, 314-324. [CrossRef]

156. Wang, H.; Zou, Z.; Wang, S.; Gong, M. Global analysis of transcriptome responses and gene expression profiles to cold stress of Jatropha curcas L. PLOS ONE 2013, 8, e82817. [CrossRef]

157. Zheng, J.; Fu, J.; Gou, M.; Huai, J.; Liu, Y.; Jian, M.; Huang, Q.; Guo, X.; Dong, Z.; Wang, H. Genome-wide transcriptome analysis of two maize inbred lines under drought stress. Plant Mol. Biol. 2010, 72, 407-421. [CrossRef]

158. Lenka, S.K.; Katiyar, A.; Chinnusamy, V.; Bansal, K.C. Comparative analysis of drought-responsive transcriptome in Indica rice genotypes with contrasting drought tolerance. Plant Biotechnol. J. 2011, 9, 315-327. [CrossRef] [PubMed]

159. Yoo, Y.-H.; Nalini Chandran, A.K.; Park, J.-C.; Gho, Y.-S.; Lee, S.-W.; An, G.; Jung, K.-H. OsPhyB-mediating novel regulatory pathway for drought tolerance in rice root identified by a global RNA-Seq transcriptome analysis of rice genes in response to water deficiencies. Front. Plant Sci. 2017, 8, 580. [CrossRef] [PubMed]

160. Wang, D.; Yang, C.; Dong, L.; Zhu, J.; Wang, J.; Zhang, S. Comparative transcriptome analyses of drought-resistant and-susceptible Brassica napus L. and development of EST-SSR markers by RNA-Seq. J. Plant Biol. 2015, 58, 259-269. [CrossRef]

161. Barghini, E.; Cossu, R.M.; Cavallini, A.; Giordani, T. Transcriptome analysis of response to drought in poplar interspecific hybrids. Genom. Data 2015, 3, 143-145. [CrossRef]

162. Müller, M.; Seifert, S.; Lübbe, T.; Leuschner, C.; Finkeldey, R. De novo transcriptome assembly and analysis of differential gene expression in response to drought in European beech. PLoS ONE 2017, 12, e0184167. [CrossRef]

163. Molina, C.; Rotter, B.; Horres, R.; Udupa, S.M.; Besser, B.; Bellarmino, L.; Baum, M.; Matsumura, H.; Terauchi, R.; Kahl, G. SuperSAGE: The drought stress-responsive transcriptome of chickpea roots. BMC Genom. 2008, 9, 553. [CrossRef]

164. Zhang, N.; Liu, B.; Ma, C.; Zhang, G.; Chang, J.; Si, H.; Wang, D. Transcriptome characterization and sequencing-based identification of drought-responsive genes in potato. Mol. Biol. Rep. 2014, 41, 505-517. [CrossRef]

165. Liu, Z.; Xin, M.; Qin, J.; Peng, H.; Ni, Z.; Yao, Y.; Sun, Q. Temporal transcriptome profiling reveals expression partitioning of homeologous genes contributing to heat and drought acclimation in wheat (Triticum aestivum L.). BMC Plant Biol. 2015, 15, 152. [CrossRef]

166. Singh, D.; Singh, C.K.; Taunk, J.; Tomar, R.S.S.; Chaturvedi, A.K.; Gaikwad, K.; Pal, M. Transcriptome analysis of lentil (Lens culinaris Medikus) in response to seedling drought stress. BMC Genom. 2017, 18, 206. [CrossRef]

167. Mun, B.G.; Lee, S.U.; Park, E.J.; Kim, H.H.; Hussain, A.; Imran, Q.M.; Lee, I.J.; Yun, B.W. Analysis of transcription factors among differentially expressed genes induced by drought stress in Populus davidiana. 3 Biotech 2017, 7, 209. [CrossRef] [PubMed]

168. Mun, B.G.; Hussain, A.; Park, E.J.; Lee, S.U.; Sharma, A.; Imran, Q.M.; Jung, K.H.; Yun, B.W. Profile and Time-Scale Dynamics of Differentially Expressed Genes in Transcriptome of Populus davidiana Under Drought Stress. Plant Mol. Biol. Rep. 2017, 35, 647-660. [CrossRef]

169. Wu, B.; Hu, Y.; Huo, P.; Zhang, Q.; Chen, X.; Zhang, Z. Transcriptome analysis of hexaploid hulless oat in response to salinity stress. PLoS ONE 2017, 12, e0171451. [CrossRef] [PubMed]

170. Yong, H.-Y.; Zou, Z.; Kok, E.-P.; Kwan, B.-H.; Chow, K.; Nasu, S.; Nanzyo, M.; Kitashiba, H.; Nishio, T. Comparative transcriptome analysis of leaves and roots in response to sudden increase in salinity in Brassica napus by RNA-seq. Biomed Res. Int. 2014, 2014, 467395. [CrossRef]

171. Postnikova, O.A.; Shao, J.; Nemchinov, L.G. Analysis of the alfalfa root transcriptome in response to salinity stress. Plant Cell Physiol. 2013, 54, 1041-1055. [CrossRef]

172. Radwan, O.; Arro, J.; Keller, C.; Korban, S.S. RNA-Seq transcriptome analysis in date palm suggests multi-dimensional responses to salinity stress. Trop. Plant Biol. 2015, 8, 74-86. [CrossRef]

173. Yamamoto, N.; Takano, T.; Tanaka, K.; Ishige, T.; Terashima, S.; Endo, C.; Kurusu, T.; Yajima, S.; Yano, K.; Tada, Y. Comprehensive analysis of transcriptome response to salinity stress in the halophytic turf grass Sporobolus virginicus. Front. Plant Sci. 2015, 6, 241. [CrossRef]

174. Aliakbari, M.; Razi, H.; Alemzadeh, A.; Tavakol, E. RNA-seq Transcriptome Profiling of the Halophyte Salicornia persica in Response to Salinity. J. Plant Growth Regul. 2021, 40, 707-721. [CrossRef]

175. De Souza, M.C.P.; da Silva, M.D.; Binneck, E.; de Lima Cabral, G.A.; Iseppon, A.M.B.; Pompelli, M.F.; Endres, L.; Kido, É.A. RNA-Seq transcriptome analysis of Jatropha curcas L. accessions after salt stimulus and unigene-derived microsatellite mining. Ind. Crop. Prod. 2020, 147, 112168. [CrossRef]

176. Armario Najera, V.; Twyman, R.M.; Christou, P.; Zhu, C. Applications of multiplex genome editing in higher plants. Curr. Opin. Biotechnol. 2019, 59, 93-102. [CrossRef]

177. Hashimoto, R.; Ueta, R.; Abe, C.; Osakabe, Y.; Osakabe, K. Efficient Multiplex Genome Editing Induces Precise, and Self-Ligated Type Mutations in Tomato Plants. Front. Plant Sci. 2018, 9, 916. [CrossRef]

178. Sovova, T.; Kerins, G.; Demnerova, K.; Ovesna, J. Genome Editing with Engineered Nucleases in Economically Important Animals and Plants: State of the Art in the Research Pipeline. Curr. Issues Mol. Biol. 2017, 21, 41-62. [PubMed]

179. Sauer, N.J.; Narvaez-Vasquez, J.; Mozoruk, J.; Miller, R.B.; Warburg, Z.J.; Woodward, M.J.; Mihiret, Y.A.; Lincoln, T.A.; Segami, R.E.; Sanders, S.L.; et al. Oligonucleotide-Mediated Genome Editing Provides Precision and Function to Engineered Nucleases and Antibiotics in Plants. Plant Physiol. 2016, 170, 1917-1928. [CrossRef] [PubMed] 
180. Osakabe, Y.; Osakabe, K. Genome editing with engineered nucleases in plants. Plant Cell Physiol. 2015, 56, 389-400. [CrossRef] [PubMed]

181. Wang, H.; La Russa, M.; Qi, L.S. CRISPR/Cas9 in Genome Editing and Beyond. Annu. Rev. Biochem. 2016, 85, 227-264. [CrossRef] [PubMed]

182. Bortesi, L.; Fischer, R. The CRISPR/Cas9 system for plant genome editing and beyond. Biotechnol. Adv. 2015, 33, 41-52. [CrossRef]

183. Jaganathan, D.; Ramasamy, K.; Sellamuthu, G.; Jayabalan, S.; Venkataraman, G. CRISPR for Crop Improvement: An Update Review. Front. Plant Sci 2018, 9, 985. [CrossRef]

184. Farhat, S.; Jain, N.; Singh, N.; Sreevathsa, R.; Dash, P.K.; Rai, R.; Yadav, S.; Kumar, P.; Sarkar, A.K.; Jain, A.; et al. CRISPR-Cas9 directed genome engineering for enhancing salt stress tolerance in rice. Semin. Cell Dev. Biol. 2019, 96, 91-99. [CrossRef]

185. Hussain, A.; Imran, Q.M.; Yun, B.-W. CRISPR/Cas9-Mediated Gene Editing in Grain Crops. In Recent Advances in Grain Crops Research; IntechOpen: London, UK, 2019; p. 9.

186. Zhang, A.; Liu, Y.; Wang, F.; Li, T.; Chen, Z.; Kong, D.; Bi, J.; Zhang, F.; Luo, X.; Wang, J.; et al. Enhanced rice salinity tolerance via CRISPR/Cas9-targeted mutagenesis of the OsRR22 gene. Mol. Breed. 2019, 39, 47. [CrossRef]

187. Santosh Kumar, V.V.; Verma, R.K.; Yadav, S.K.; Yadav, P.; Watts, A.; Rao, M.V.; Chinnusamy, V. CRISPR-Cas9 mediated genome editing of drought and salt tolerance (OsDST) gene in indica mega rice cultivar MTU1010. Physiol. Mol. Biol. Plants 2020, 26, 1099-1110. [CrossRef]

188. Osakabe, Y.; Watanabe, T.; Sugano, S.S.; Ueta, R.; Ishihara, R.; Shinozaki, K.; Osakabe, K. Optimization of CRISPR/Cas9 genome editing to modify abiotic stress responses in plants. Sci. Rep. 2016, 6, 26685. [CrossRef]

189. Zhao, Y.; Zhang, C.; Liu, W.; Gao, W.; Liu, C.; Song, G.; Li, W.-X.; Mao, L.; Chen, B.; Xu, Y.; et al. An alternative strategy for targeted gene replacement in plants using a dual-sgRNA/Cas9 design. Sci Rep. 2016, 6, 23890. [CrossRef] [PubMed]

190. Roca Paixao, J.F.; Gillet, F.X.; Ribeiro, T.P.; Bournaud, C.; Lourenco-Tessutti, I.T.; Noriega, D.D.; Melo, B.P.; de Almeida-Engler, J.; Grossi-de-Sa, M.F. Improved drought stress tolerance in Arabidopsis by CRISPR/dCas9 fusion with a Histone AcetylTransferase. Sci. Rep. 2019, 9, 8080. [CrossRef]

191. Shi, J.; Gao, H.; Wang, H.; Lafitte, H.R.; Archibald, R.L.; Yang, M.; Hakimi, S.M.; Mo, H.; Habben, J.E. ARGOS8 variants generated by CRISPR-Cas9 improve maize grain yield under field drought stress conditions. Plant Biotechnol. J. 2017, 15, 207-216. [CrossRef] [PubMed]

192. Char, S.N.; Neelakandan, A.K.; Nahampun, H.; Frame, B.; Main, M.; Spalding, M.H.; Becraft, P.W.; Meyers, B.C.; Walbot, V.; Wang, K.; et al. An Agrobacterium-delivered CRISPR/Cas9 system for high-frequency targeted mutagenesis in maize. Plant Biotechnol. J. 2017, 15, 257-268. [CrossRef] [PubMed]

193. Chen, R.; Xu, Q.; Liu, Y.; Zhang, J.; Ren, D.; Wang, G.; Liu, Y. Generation of Transgene-Free Maize Male Sterile Lines Using the CRISPR/Cas9 System. Front. Plant Sci. 2018, 9, 1180. [CrossRef]

194. Feng, C.; Su, H.; Bai, H.; Wang, R.; Liu, Y.; Guo, X.; Liu, C.; Zhang, J.; Yuan, J.; Birchler, J.A.; et al. High-efficiency genome editing using a dmc1 promoter-controlled CRISPR/Cas9 system in maize. Plant Biotechnol. J. 2018, 16, 1848-1857. [CrossRef]

195. Feng, C.; Yuan, J.; Wang, R.; Liu, Y.; Birchler, J.A.; Han, F. Efficient Targeted Genome Modification in Maize Using CRISPR/Cas9 System. J. Genet. Genom. 2016, 43, 37-43. [CrossRef]

196. Kim, D.; Alptekin, B.; Budak, H. CRISPR/Cas9 genome editing in wheat. Funct. Integr. Genom. 2018, 18, 31-41. [CrossRef]

197. Bhowmik, P.; Ellison, E.; Polley, B.; Bollina, V.; Kulkarni, M.; Ghanbarnia, K.; Song, H.; Gao, C.; Voytas, D.F.; Kagale, S. Targeted mutagenesis in wheat microspores using CRISPR/Cas9. Sci. Rep. 2018, 8, 6502. [CrossRef]

198. Sanchez-Leon, S.; Gil-Humanes, J.; Ozuna, C.V.; Gimenez, M.J.; Sousa, C.; Voytas, D.F.; Barro, F. Low-gluten, nontransgenic wheat engineered with CRISPR/Cas9. Plant Biotechnol J. 2018, 16, 902-910. [CrossRef]

199. Singh, M.; Kumar, M.; Albertsen, M.C.; Young, J.K.; Cigan, A.M. Concurrent modifications in the three homeologs of Ms45 gene with CRISPR-Cas9 lead to rapid generation of male sterile bread wheat (Triticum aestivum L.). Plant Mol. Biol. 2018, 97, 371-383. [CrossRef] [PubMed]

200. Li, C.H.; Wang, G.; Zhao, J.L.; Zhang, L.Q.; Ai, L.F.; Han, Y.F.; Sun, D.Y.; Zhang, S.W.; Sun, Y. The Receptor-Like Kinase SIT1 Mediates Salt Sensitivity by Activating MAPK3/6 and Regulating Ethylene Homeostasis in Rice. Plant Cell 2014, 26, 2538-2553. [CrossRef] [PubMed]

201. Ma, Y.; Dai, X.; Xu, Y.; Luo, W.; Zheng, X.; Zeng, D.; Pan, Y.; Lin, X.; Liu, H.; Zhang, D.; et al. COLD1 confers chilling tolerance in rice. Cell 2015, 160, 1209-1221. [CrossRef]

202. Shen, C.; Que, Z.; Xia, Y.; Tang, N.; Li, D.; He, R.; Cao, M. Knock out of the annexin gene OsAnn3 via CRISPR/Cas9-mediated genome editing decreased cold tolerance in rice. J. Plant Biol. 2017, 60, 539-547. [CrossRef]

203. Ye, Y.; Li, P.; Xu, T.; Zeng, L.; Cheng, D.; Yang, M.; Luo, J.; Lian, X. OsPT4 Contributes to Arsenate Uptake and Transport in Rice. Front. Plant Sci 2017, 8, 2197. [CrossRef]

204. Tang, L.; Mao, B.; Li, Y.; Lv, Q.; Zhang, L.; Chen, C.; He, H.; Wang, W.; Zeng, X.; Shao, Y.; et al. Knockout of OsNramp5 using the CRISPR/Cas9 system produces low Cd-accumulating indica rice without compromising yield. Sci. Rep. 2017, 7, 1-12. [CrossRef]

205. Nieves-Cordones, M.; Mohamed, S.; Tanoi, K.; Kobayashi, N.I.; Takagi, K.; Vernet, A.; Guiderdoni, E.; Périn, C.; Sentenac, H.; Véry, A.-A. Production of low-Cs+ rice plants by inactivation of the $\mathrm{K}+$ transporter Os HAK 1 with the CRISPR-Cas system. Plant J. 2017, 92, 43-56. [CrossRef]

206. Park, J.J.; Dempewolf, E.; Zhang, W.; Wang, Z.Y. RNA-guided transcriptional activation via CRISPR/dCas9 mimics overexpression phenotypes in Arabidopsis. PLoS ONE 2017, 12, e0179410. [CrossRef] [PubMed] 
207. Zhang, Z.; Li, J.; Pan, Y.; Li, J.; Shi, H.; Zeng, Y.; Guo, H.; Yang, S.; Zheng, W.; Yu, J.; et al. Natural variation in CTB4a enhances rice adaptation to cold habitats. Nat. Commun. 2017, 8, 14788. [CrossRef]

208. Tang, N.; Ma, S.; Zong, W.; Yang, N.; Lv, Y.; Yan, C.; Guo, Z.; Li, J.; Li, X.; Xiang, Y.; et al. MODD Mediates Deactivation and Degradation of OsbZIP46 to Negatively Regulate ABA Signaling and Drought Resistance in Rice. Plant Cell 2016, 28, $2161-2177$. [CrossRef] [PubMed]

209. Li, X.-M.; Chao, D.-Y.; Wu, Y.; Huang, X.; Chen, K.; Cui, L.-G.; Su, L.; Ye, W.-W.; Chen, H.; Chen, H.-C.; et al. Natural alleles of a proteasome $\alpha 2$ subunit gene contribute to thermotolerance and adaptation of African rice. Nat. Genet. 2015, 47, 827-833. [CrossRef] [PubMed]

210. Zeng, D.D.; Yang, C.C.; Qin, R.; Alamin, M.; Yue, E.K.; Jin, X.L.; Shi, C.H. A guanine insert in OsBBS1 leads to early leaf senescence and salt stress sensitivity in rice (Oryza sativa L.). Plant Cell Rep. 2018, 37, 933-946. [CrossRef] [PubMed]

211. Shim, J.S.; Oh, N.; Chung, P.J.; Kim, Y.S.; Choi, Y.D.; Kim, J.K. Overexpression of OsNAC14 Improves Drought Tolerance in Rice. Front. Plant Sci 2018, 9, 310. [CrossRef]

212. Wang, L.; Chen, L.; Li, R.; Zhao, R.; Yang, M.; Sheng, J.; Shen, L. Reduced Drought Tolerance by CRISPR/Cas9-Mediated SIMAPK3 Mutagenesis in Tomato Plants. J. Agric. Food Chem. 2017, 65, 8674-8682. [CrossRef] [PubMed]

213. Huang, Y.; Guo, Y.; Liu, Y.; Zhang, F.; Wang, Z.; Wang, H.; Wang, F.; Li, D.; Mao, D.; Luan, S.; et al. 9-cis-Epoxycarotenoid Dioxygenase 3 Regulates Plant Growth and Enhances Multi-Abiotic Stress Tolerance in Rice. Front. Plant Sci $2018,9,162$. [CrossRef]

214. Duan, Y.B.; Li, J.; Qin, R.Y.; Xu, R.F.; Li, H.; Yang, Y.C.; Ma, H.; Li, L.; Wei, P.C.; Yang, J.B. Identification of a regulatory element responsible for salt induction of rice OsRAV2 through ex situ and in situ promoter analysis. Plant Mol. Biol. 2016, 90, 49-62. [CrossRef] 